\title{
A history of habitat dynamics: Characterizing 35 years of stand replacing disturbance
}

\author{
Joanne C. White, Michael A. Wulder, Cristina Gómez, and Gordon Stenhouse
}

\begin{abstract}
Landscape change, specifically habitat loss and modification, is thought to have an impact on the health, productivity, distribution, and survival of grizzly bears (Ursus arctos L.). Although grizzly bears may preferentially seek out areas of anthropogenic disturbances for foraging opportunities, research has found that grizzly bears experience greater mortality in these areas as a result of increased human access. Additional insights on the location and rates of anthropogenic-driven landscape change are required to better understand related impacts upon grizzly bears. In this study, a time series of 14 Landsat MSS, TM, and ETM + images were used to retrospectively document and quantify the rate of landscape change over a 35-year period from 1973 to 2008 in a $13507 \mathrm{~km}^{2}$ analysis area in western Alberta, Canada. The study area is located within a larger region that contains the highest density of grizzly bears in Alberta and has experienced increasingly intensive forest harvesting and oil and gas exploration activities during this period. To accommodate the differing spectral channels from MSS to TM/ETM + sensors, the arctangent of the angle of the Tasseled Cap greenness-to-brightness components was computed for each image year, with sequential image pairs differenced and a threshold applied to identify stand-replacing disturbance events.

Results indicated that $11 \%$ of the analysis area experienced some form of stand-replacing disturbance (e.g., cutblocks, roads, oil and gas well sites, seismic lines, power lines, pipelines, blowdown) between 1973 and 2008. The greatest proportion of this change (by area) occurred between 2004 and 2006 (24\%), while the lowest proportion occurred between 2000 and 2001 $(2 \%)$. Although the number of change events has fluctuated over time, with a minimum of 2888 change events between 1976 and $1978(2 \%)$ and a maximum of 36623 change events between 2004 and 2006 (29\%), the mean size of change events has decreased over time: prior to 1995, mean event size was greater than 1.5 ha; after 1995, it was less than 1.5 ha. The annual rate of change was greatest between 2004 and $2006(-1.25 \%)$, and lowest between 1981 and $1990(-0.04 \%)$. Consideration of changes within the context of units relevant to grizzly bear management (i.e., grizzly bear watershed units and core or secondary habitat areas) indicate that the amount and rate of change was not spatially or temporally uniform across the study area. While the average change event size has decreased over time, the increasing number of change events has resulted in a larger aggregate area of change in more recent years. Landsat imagery provided a large-area, synoptic, and consistent characterization of 35 years of stand-replacing disturbance in our study area, providing information that enables an improved understanding of the complex interactions between grizzly bear distribution, abundance, health, survival, and habitat.
\end{abstract}

Résumé. Les changements dans le paysage, en particulier la perte et la modification d'habitats, sont perçus comme ayant un impact sur la santé, la productivité, la distribution et la survie des grizzlys (Ursus arctos L.). Bien que les grizzlys aient tendance à rechercher de préférence des zones de perturbations anthropogéniques pour les opportunités de fourrage qu'elles offrent, la recherche a permis de découvrir que les grizzlys connaissent un taux de mortalité plus grand dans ces zones à cause de la présence plus généralisée d'humains. Il est nécessaire d'avoir une information supplémentaire sur la localisation et le taux des changements du paysage d'origine anthropogénique pour mieux comprendre les impacts associés sur les grizzlys. Dans cette étude, une série temporelle de 14 images de MSS, de TM et de ETM + de Landsat a été utilisée pour documenter et quantifier rétrospectivement le taux de changement dans le paysage au cours d'une période de 35 ans, soit de 1973 à 2008, dans une zone d'étude couvrant $13507 \mathrm{~km}^{2}$ dans l'ouest de l'Alberta, au Canada. La zone d'étude s'inscrit dans une région plus vaste qui enregistre la plus haute densité de grizzlys en Alberta et qui a été soumise à des opérations forestières ainsi que des activités d'exploration pétrolière et gazière de plus en plus intensives au cours des 35 dernières années. Pour accommoder les bandes spectrales divergentes des capteurs MSS et TM/ETM +, l'arc tangente de l'angle des composantes de verdure par rapport à la brillance de l'espace indiciel a été calculée pour chaque année à partir des couplets d'images séquentiels différenciés et un seuil a été appliqué pour identifier les événements perturbateurs qui ont entraîné le remplacement du peuplement.

Received 3 September 2010. Accepted 21 January 2011. Published on the Web at http://pubs.casi.ca/journal/cjrs on 31 October 2011.

Joanne C. White, and Michael A. Wulder. ${ }^{1}$ Canadian Forest Service (Pacific Forestry Centre), Natural Resources Canada, Victoria, British Columbia, V8Z 1M5, Canada.

Cristina Gómez. Sustainable Forest Management Research Institute, ETS de Ingenierías Agrarias, Universidad de Valladolid, Palencia, 34004, Spain.

Gordon Stenhouse. Foothills Research Institute, Hinton, Alberta, Canada T7V 1X6.

${ }^{1}$ Corresponding author (e-mail: mwulder@nrcan.gc.ca). 
Les résultats ont montré que $11 \%$ de la zone d'analyse a connu une certaine forme de perturbation entraînant le remplacement du peuplement (p. ex. blocs de coupe, routes, sites de puits pétrolier ou gazier, lignes séismiques, lignes de transport d'énergie, pipelines, zone de chablis) entre 1973 et 2008. La plus grande partie du changement (en superficie) s'est manifestée entre 2004 et 2006 (24\%), alors que la portion la plus faible a été observée entre 2000 et 2001 (2\%). Bien que le nombre d'événements de changement ait fluctué dans le temps, avec un minimum de 2888 événements entre 1976 et $1978(2 \%)$ et un maximum de 36623 événements entre 2004 et 2006 (29\%), la dimension moyenne des événements a diminué dans le temps : avant 1995, la superficie moyenne des événements était supérieure à 1,5 ha; après 1995, celle-ci était inférieure à 1,5 ha. Le taux annuel de changement était à son maximum entre 2004 et $2006(-1,25 \%)$ et à son plus faible entre 1981 et $1990(-0,04 \%)$. La prise en compte des changements dans le contexte des unités pertinentes de gestion des grizzlys (c.à.d., les unités de bassin-versant des grizzlys et les zones d'habitats principaux/secondaires) montre que le nombre et le taux de changements n'étaient pas uniformes spatialement ou temporellement sur l'ensemble de la zone d'étude. Bien que la superficie moyenne des événements de changement ait diminué dans le temps, le nombre croissant d'événements a résulté en une superficie globale de changement plus grande au cours des dernières années. Les images de Landsat ont permis d'établir une caractérisation à grande échelle, synoptique et cohérente de 35 années de perturbations entraînant le remplacement du peuplement dans notre zone d'étude, apportant ainsi une information qui permettra d'assurer une meilleure connaissance des interactions complexes entre la répartition, l'abondance, la santé, la survie et l'habitat des grizzlys.

[Traduit par le Rédaction]

\section{Introduction}

The spatial and temporal distribution of natural and anthropogenic landscape disturbances influence grizzly bear (Ursus arctos L.) habitat use (Nielsen, 2004; Schwartz et al., 2006; Berland et al., 2008). Although grizzly bears may preferentially seek out disturbed areas for high-quality foraging opportunities (Nielsen et al., 2004a), the risk of bear mortality in these areas is greater as a result of increased human access (Benn and Herrero, 2002; McLellan and Shackleton, 1988; Nielsen et al., 2004b; Schwartz et al., 2010), with the mortality related primarily to hunting and (or) poaching events and, to a lesser degree, collisions with motor vehicles.

Models of grizzly bear distribution and abundance require information on anthropogenic activities (Boone and Hunter, 1996; Apps et al., 2004), along with grizzly bear seasonal food distribution (Nielsen et al., 2010). With this information, retrospective analyses of grizzly bear distribution and abundance are undertaken to evaluate the efficacy of past management practices and to identify future conservation issues (Pease and Mattson, 1999; Wieglus and Bunnell, 2000; Berland et al., 2008). Spatial models of grizzly bear mortality seek to identify the location of mortality sinks - defined as areas with a relatively higher risk of grizzly mortality (Nielsen et al., 2004b). These models are premised on the assumption that grizzly bear mortality is related to a combination of habitat value and human access - both of which are related to anthropogenic landscape disturbance. There is also a recognized but often unstated belief that human attitudes and behaviours towards bears influence grizzly bear mortality rates (Mattson and Merrill, 2002).

Retrospective data that represents a chronosequence of disturbance events, provides insights into human use of the landscape over time, and aids in quantifying the cumulative impact of natural and human disturbance, is a useful information source for grizzly bear modeling. These data can provide insights into the current distribution and abundance for a long-lived species such as the grizzly bear. The Landsat program's image archive provides a continuous 38-year record of over two million images (Wulder et al., 2008a). With the Landsat archive now freely available through web-enabled download (Woodcock et al., 2008), an increasing number of studies have taken advantage of a lengthy time series of Landsat images to retrospectively quantify the rate and amount of natural and anthropogenic disturbances in forest environments (i.e., Schroeder et al., 2007; Masek et al., 2008; Bergen et al., 2008; Goodwin et al., 2008; Huang et al., 2009). Remotely sensed data can provide a synoptic and consistent source of data for large-area characterization of forests and Landsat data have a particularly useful combination of a large spatial footprint and a sufficiently fine spatial resolution to resolve the majority of natural and anthropogenic forest disturbances (Wulder et al., 2008a). While approaches may vary, change analysis of Landsat images typically results in spatially explicit disturbance outputs with a high level of detail (Coppin et al., 2004; Kennedy et al., 2009), with object resolving capacity limited by spatial resolution and factors including the size, shape, and spectral contrast of a given change event (Stewart et al., 2009). For concerns related to the continuity of measures from the Landsat program, readers are referred to Wulder et al. (2011).

Using a time series of Landsat data enables the examination of temporal trends assessed against a normalized consistent time series of spectral data (Powell et al., 2010). The assessment of long-term trends minimizes error associated with factors such as phenology, solar angle, and (or) atmospheric conditions. Using two dates of imagery can capture change-using more than two dates of imagery enables the characterization of rates of change (Gillanders et al., 2008). A time series affords other advantages as well, including more precise dating of stand-replacing change events and detection of more subtle or multiyear events (i.e., insects or pathogens, stand regeneration). Furthermore, long-term analysis of change 
can provide insights into the drivers of change and enable implementation of more effective management strategies (Kennedy et al., 2009). The spatial and temporal richness of change information from a time series of remotely sensed imagery does pose some challenges for the end user-primarily the paucity of independent reference data that are available for validation or corroboration. Furthermore, the reference data that are available are not infallible and often lack appropriate metadata that details the origin and quality of reference data sources, and this is particularly a concern for older data.

As one would expect, the interactions between grizzly bears, humans, and the environment are complex (Schwartz et al., 2003). Grizzly bears occupy large home ranges, with variability in the abundance and quality of habitat conditions expected. Disturbance is among many factors that define and influence habitat conditions (Nielsen, 2004). The actual occurrence of a stand-replacing disturbance may be considered as providing new forage opportunities, while at the same time often provides new human access (Boyce et al., 2009). The impact of disturbance location and rates upon grizzly bear distribution, abundance, and health requires additional research supported by appropriate disturbance datasets. In support of this information need, we investigate the capacity to build a long-term disturbance record from satellite imagery that will inform on the disturbance aspects that impact grizzly bear habitat. Objectives of this study include: investigation of a spectral index that enables us to bridge across Landsat sensors; generation of disturbance maps and rates; and interpretation and characterization of the changes found in the context of the study area and grizzly bear relevant management subunits to learn more about and disturbance conditions and trends in grizzly bear habitat units.

\section{Methods}

\section{Study area}

The study area covers approximately $15547 \mathrm{~km}^{2}$ of the boreal and subalpine forest regions (Rowe, 1972) on the eastern side of the Rocky Mountains, Alberta, Canada (Figure 1). Lodgepole pine (Pinus contorta Dougl. ex Loudon), trembling aspen (Populus tremuloides Michx), and balsam poplar (Populus balsamifera L.) are prevalent post-fire pioneer species. Other species found in the area include white spruce (Picea glauca (Moench) Voss) and black spruce (Picea mariana (Mill.) BSP), and, less frequently, white birch (Betula papyrifera Marsh.), tamarack (Larix laricina (Du Roi) K. Kock), balsam fir (Abies balsamea (L.)), Engelmann spruce (Picea engelmannii), and alpine fir (Abies lasiocarpa (Hook.) Nutt.). Elevation in the study area ranges from $600 \mathrm{~m}$ to $2500 \mathrm{~m}$.

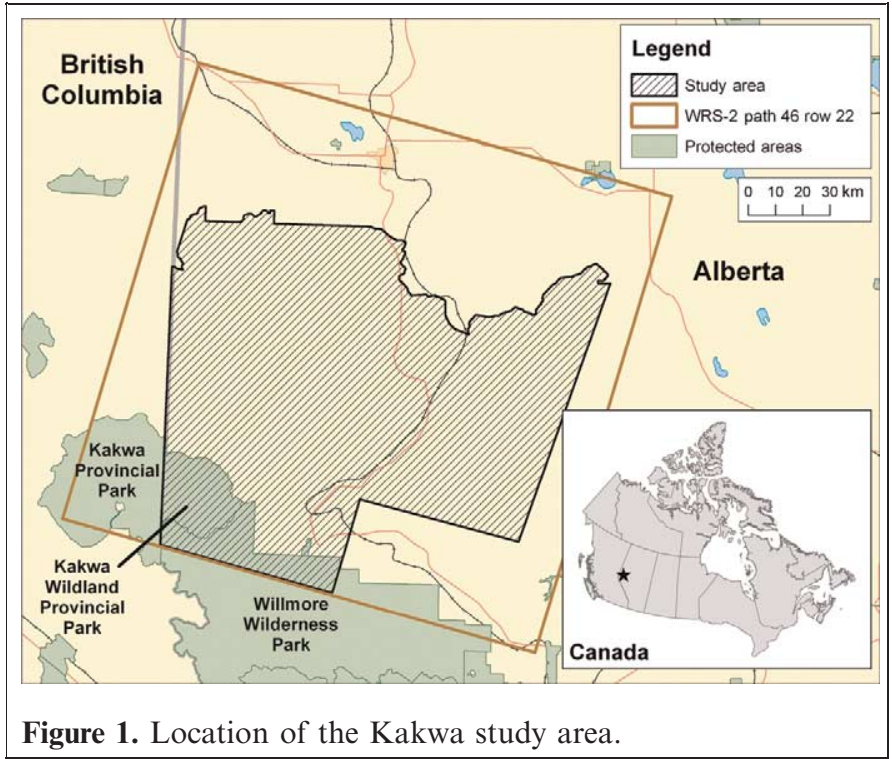

The area contains abundant natural resources (Alberta Sustainable Resource Development, 2009) and also provides important habitat for two "threatened" species in Alberta: woodland caribou and grizzly bears (Ursus arctos L.). A network of federal and provincial protected areas extends to the southwest of the study area (Figure 1), with approximately $9 \%$ of the study area protected. The protected area includes high elevation areas in portions of Kakwa Provincial Park (British Columbia), Kakwa Wildland Provincial Park (Alberta), and Willmore Wilderness Park (Alberta). The protected portion of the study area has a mean elevation of $1682 \mathrm{~m}$, compared with a mean elevation of $1165 \mathrm{~m}$ for the study area as a whole.

The study area is located within the Grande Cache Bear Management Area (BMA) - an area in which grizzly bear population size and density estimates were made from a DNA population inventory utilizing hair snares conducted in June and July of 2008. The Grande Cache BMA is the largest such area in Alberta and "contains a significant proportion of parks and protected areas" (Alberta Grizzly Bear Inventory Team, 2009). This BMA, which is adjacent to Jasper National Park to the southwest, contains the largest population of grizzlies in Alberta, with an estimated population of 353 bears ( $\mathrm{SE}=53.52, \mathrm{CI}=288-516)$. The grizzly population density of the BMA is estimated to be 18.11 bears per $1000 \mathrm{~km}^{2}$ (Alberta Grizzly Bear Inventory Team, 2009). Data from the 2008 population inventory indicate that the large population of grizzly bears in the Grande Cache BMA is supported by high densities of grizzly bears in the Kakwa and Willmore protected areas (Festa-Bianchet, 2010)

Resource extraction activities such as oil and gas exploration and development, mining, and forest harvesting have taken place in the area since the 1950s (Andison, 1998); however, the majority of forest harvesting has occurred since the 1980s (Ripley et al., 2005). The study area is part of the Western Canadian Sedimentary Basin, which represents one 
of the world's largest hydrocarbon reserves (Schneider et al., 2003). In particular, the Kakwa is of interest for natural gas development (Tilley and Muehlenbachs, 2006), as it is part of the undisturbed "Deep Basin Gas Trap" (Masters, 1984) with gas reserves that are estimated at $4.8 \times 10^{11} \mathrm{~m}^{3}$ (Welte et al., 1984).

\section{Reference data}

The lack of quality ground reference data is a recurring challenge for the calibration and validation of remotely sensed image products (Foody, 2009). It is often assumed that ground reference data are perfectly correct and uncertainty in the ground reference data is either unknown or not accounted for (Mann and Rothley, 2006). Since all potential sources of error associated with the reference data could translate into error in the change estimates (Foody, 2008), it is useful to attempt to account for these errors (Foody, 2009). The perils of using pre-existing data for calibration can include geolocational mismatches, discrepancies in spatial scale between the image and the reference data, differences in features or classes that are mapped, and temporal discrepancies between the image and the reference data (Wulder et al., 2006).

Ground reference data were compiled from a variety of sources. Information on pipelines, and oil and gas well sites was compiled from Government of Alberta data sources and aerial photography. Information on cutblocks was compiled from Alberta Vegetation Inventory data as well as from various forest management agreement holders. Information on roads was compiled from a 2008 road network file (Statistics Canada, 2008). Only data corresponding to the timeframe of the Landsat time series (1973-2008) were included in the reference dataset. The reference dataset, as one would expect, does not capture all changes nor does it have correct notation of exactly when the change occurred. Photography or silvicultural data are required to update the change database. Years can pass between capture of photography, resulting in a lack of precision in dating of disturbances. The years when photography was captured will not necessarily be in sync with the imagery available in the time-series. Area-wide capture of photography was not undertaken over this study area, as parks and protected areas - important habitats - are not commonly included in resource management inventories.

\section{Image processing}

The Landsat time series consists of 14 growing-season (July-September) images acquired between 1973 and 2008 (Table 1) with either the Landsat Multi-Spectral Scanner (MSS), Thematic Mapper (TM), or Enhanced Thematic Mapper $(\mathrm{ETM}+)$ instruments (Table 2). Based on image quality and cloud-free status, the 1995 TM image was selected as the reference image for both image-to-image
Table 1. Landsat imagery used in the study.

\begin{tabular}{llll}
\hline Sensor & Path/Row & Date (yyyy-mm-dd) & Sun elevation $\left(^{\circ}\right)$ \\
\hline MSS & $50 / 22$ & $1973-09-16$ & 36.21 \\
MSS & $50 / 22$ & $1976-09-27$ & 30.40 \\
MSS & $50 / 22$ & $1978-07-25$ & 49.00 \\
MSS & $50 / 22$ & $1981-08-14$ & 46.10 \\
TM & $46 / 22$ & $1990-09-06$ & 37.38 \\
TM & $46 / 22$ & $1991-07-23$ & 50.25 \\
TM & $46 / 22$ & $1995-09-04$ & 36.99 \\
TM & $46 / 22$ & $1997-09-25$ & 32.21 \\
ETM+ & $46 / 22$ & $2000-09-25$ & 32.82 \\
ETM + & $46 / 22$ & $2001-09-28$ & 31.70 \\
ETM + & $46 / 22$ & $2002-09-15$ & 36.48 \\
TM & $46 / 22$ & $2004-08-11$ & 47.31 \\
TM & $46 / 22$ & $2006-06-30$ & 55.86 \\
TM & $46 / 22$ & $2008-08-06$ & 48.80 \\
\hline
\end{tabular}

geometric registration and subsequent atmospheric correction and normalization.

The majority of Landsat images were received orthocorrected, with the exception of the MSS 1981 and TM 1997 images, which were received in raw format. These two raw images were orthocorrected using Toutin's model (Toutin, 1995) and registered to the TM 1995 base image using 250 GCPs and the thin plate spline algorithm. All of the MSS images (Table 1) were resampled from their original $57 \mathrm{~m}$ spatial resolution to $30 \mathrm{~m}$. Using an image-to-image registration process, all images were co-registered to the $1995 \mathrm{TM}$ image with an RMSE of less than $30 \mathrm{~m}$. To ensure that confounding characteristics are not included in the change analysis, areas of clouds and cloud shadows in the images are masked out using a combination of automated and

Table 2. Comparative characteristics of the Landsat sensors.

\begin{tabular}{|c|c|c|c|c|c|}
\hline Sensor & Landsat $1-3$ & $\begin{array}{l}\text { Landsat } \\
4-5\end{array}$ & $\begin{array}{l}\text { Wavelength } \\
(\mu \mathrm{m})\end{array}$ & $\begin{array}{l}\text { Image } \\
\text { extent } \\
(\mathrm{km})\end{array}$ & $\begin{array}{l}\text { Pixel } \\
\text { size } \\
(\mathrm{m})\end{array}$ \\
\hline \multirow[t]{5}{*}{ MSS } & 4 & 1 & $0.5-0.6$ & \multirow{5}{*}{$170 \times 185$} & \multirow{5}{*}{80} \\
\hline & 5 & 2 & $0.6-0.7$ & & \\
\hline & 6 & 3 & $0.7-0.8$ & & \\
\hline & 7 & 4 & $0.8-1.1$ & & \\
\hline & Landsat $4-5$ & & & & \\
\hline \multirow[t]{7}{*}{$\mathrm{TM}$} & 1 & & $0.45-0.52$ & \multirow{7}{*}{$170 \times 183$} & \multirow{7}{*}{30} \\
\hline & 2 & & $0.52-0.60$ & & \\
\hline & 3 & & $0.63-0.69$ & & \\
\hline & 4 & & $0.76-0.90$ & & \\
\hline & 5 & & $1.55-1.75$ & & \\
\hline & 7 & & $2.08-2.35$ & & \\
\hline & Landsat 7 & & & & \\
\hline \multirow[t]{6}{*}{$\mathrm{ETM}+$} & 1 & & $0.45-0.52$ & \multirow{6}{*}{$170 \times 183$} & \multirow{6}{*}{30} \\
\hline & 2 & & $0.52-0.60$ & & \\
\hline & 3 & & $0.63-0.69$ & & \\
\hline & 4 & & $0.77-0.90$ & & \\
\hline & 5 & & $1.55-1.75$ & & \\
\hline & 7 & & $2.09-2.35$ & & \\
\hline
\end{tabular}


Table 3. Coefficients used for calculation of the Tasseled Cap Transformation brightness and greenness components.

\begin{tabular}{llrrrrrr}
\hline Sensor & Component & \multicolumn{1}{l}{$\mathrm{R}$} & \multicolumn{1}{l}{$\mathrm{G}$} & \multicolumn{1}{l}{$\mathrm{B}$} & NIR & SWIR1 & SWIR2 \\
\hline MSS & Brightness & 0.433 & 0.632 & 0.586 & 0.264 & N/A & N/A \\
& Greenness & -0.290 & -0.562 & 0.600 & 0.491 & N/A & N/A \\
TM & Brightness & 0.3037 & 0.2793 & 0.4343 & 0.5585 & 0.5082 & 0.1863 \\
& Greenness & -0.2848 & -0.2435 & -0.5436 & 0.7243 & 0.0840 & -0.1800 \\
ETM + & Brightness & 0.3561 & 0.3972 & 0.3904 & 0.6966 & 0.2286 & 0.1596 \\
& Greenness & -0.3344 & -0.3544 & -0.4556 & 0.6966 & -0.0242 & -0.2630 \\
\hline
\end{tabular}

manual approaches and were thereby excluded from subsequent processing and analysis.

Images were then converted to top-of-atmosphere radiance using the approach of Han et al. (2007) and the coefficients recommended by Chander et al. (2009). The Tasseled Cap Transformation (TCT) brightness and greenness components (Kauth and Thomas, 1976; Crist and Cicone, 1984; Huang et al., 2002) were calculated and normalized using the Iteratively Reweighted Multivariate Alteration Detection (IRMAD) algorithm (Canty et al., 2004; Schroeder et al., 2006), as per Powell et al. (2008) to minimize sun-sensor-view angle effects. The MAD components are invariant under linear transformations (Nielsen et al., 1998; Canty et al., 2004), thus making it possible to use MAD with vegetation indices that are linear transformations, such as the TCT. The brightness and greenness components derived from the 1995 Landsat TM image were used as the reference source for MAD. Finally, a water feature mask (generated from National Hydrology Network data) and an elevation mask (representing areas greater than $1700 \mathrm{~m}$, relating the local vegetation to alpine transition) were combined with the cloud/shadow mask already applied to the normalized images. The area remaining for analysis, after all masks were applied, was approximately $13507 \mathrm{~km}^{2}$.

\section{The Tasseled Cap Angle}

The TCT (Kauth and Thomas, 1976; Crist and Cicone, 1984; Crist and Kauth, 1986; Huang et al., 2002), a linear transform of the original Landsat spectral space, has been broadly employed in forestry applications (Cohen and Goward, 2004) to characterize forest structure (Hansen et al., 2001), condition (Wulder et al., 2006; Healey et al., 2006), successional state (Peterson and Nilson, 1993, Helmer et al., 2000), and for change detection (Jin and Sader, 2005). The first two orthogonal components of the TCT, brightness and greenness form the vegetation plane (Crist and Cicone, 1984). The study of a forest stands' spectral behaviour in the vegetation plane provides insights into forest cover densities (Cohen et al., 1995; Cohen et al., 1998) and forest development stages (Price and Jakubauskas, 1998). The brightness component is by definition a positive value, whereas greenness depends on the contrast between the visible and near infrared bands, with exposed soil having negative values (Gillanders et al., 2008) and vegetated areas having positive values. Based upon spectral bands (i.e., no SWIR on Landsat MSS; Table 2), use of an index based upon visible and near infrared channels provides a means to form a bridge between MSS and TMETM + imagery (Powell et al., 2008).

The tasseled cap angle (TCA), defined as the angle formed by greenness and brightness in the vegetation plane (Equation 1), condenses in a single value the information of the relation greenness to brightness and represents the proportion of vegetation to nonvegetation. The TCA represents the arctangent of the normalized greenness and brightness tasseled cap components (Powell et al., 2010)

$\mathrm{TCA}=\arctan ($ greenness $/$ brightness $)$

A number of studies in coniferous forests have confirmed higher values of greenness and lower values of brightness in dense cover classes when compared with open stands or clearcuts (Cohen et al., 1995, Price and Jakubauskas, 1998). Accordingly, dense forest stands are expected to show higher TCA values than more open stands or bare soil. An analysis of variance (ANOVA) is implemented to determine the uniqueness of the TCA values by land cover classes dominant over the study area (derived from Earth Observation for Sustainable Development of Forests, Wulder et al. (2008b).

\section{Change detection}

Changes were detected by differencing TCA image pairs and selecting and applying a threshold that enabled the identification of change features of interest (i.e., standreplacing disturbances such as cutblocks, roads, oil and gas well sites, seismic lines, power lines, pipelines, etc.) for each time period. The location, number, and size of change events were summarized by time period. In addition, the rate of change was calculated using the approach of Puyravaud (2003), who proposed a method for standardizing the calculation of the annual rate of forest cover change. In the context of this study, Puyravaud's formula (Equation 2) is used to determine the annual rate of land cover change, where change events are represented by features such as clearcuts and oil and gas well sites:

Change rate $=\left[1 /\left(t_{2}-t_{1}\right)\right] \times \ln \left(A_{2} / A_{1}\right)$

where $A_{1}$ and $A_{2}$ represent the area without change at time $t_{1}$ and $t_{2}$, respectively. The Puyravaud formula was calculated 
for each decade and for each time period, and is interpreted as the rate at which areas without change are converted to areas with change; areas without change are either increasing $(+)$ or decreasing $(-)$.

\section{Rates of change}

Currently, researchers are investigating grizzly bear response (both individual and population level) to annual rates of change; therefore, for the purposes of this study, the rates of change generated from the Landsat time series should be compared with the rates of change generated from the reference data. Rates of change were generated for the study area as a whole, for areas of core and secondary habitat, and for individual grizzly bear watershed units (GBWU) within the study area (Figure 2). Areas of core habitat are considered areas of high habitat value and low mortality risk, while areas of secondary habitat are identified as areas of good habitat that accommodate the broader range of grizzly bears (Nielsen et al., 2009). The GBWUs are management units based on major watersheds that have been subdivided along heights of land and occasionally along watercourses, in order to approximate the size of an adult female grizzly bear's home range (i.e., approximately $700 \mathrm{~km}^{2}$ ). The GBWUs were defined by Alberta Sustainable Resource Management as an appropriate landscape unit for generating, reporting, and monitoring grizzly bear habitat metrics. Of the 22 GBWUs that intersect our study area, 14 are considered core habitat and 8 are considered secondary habitat. Four of the GBWUs are protected, two in provincial parks and two in the Willmore Wilderness area. To investigate the differences in the rates of change we use the formula: [(reference_rate - Landsat_rate)/reference_rate]. With the aforementioned difficulties in creating a traditional error matrix for the image change to a valid independent reference of change, we choose to compare the rates of change extracted from the imagery to that available from a forest inventory that has been updated for harvesting. From a bear habitat and management perspective, areawide spatially explicit estimates of rates of change are important.

\section{Results}

\section{The Tasseled Cap Angle}

The TCA was used as the basis for change detection in this study. The three dominant land cover types in the study area (circa 2000) were dense coniferous forest, shrub, and herb (Wulder et al., 2008b), which occupied 39\%, 9\%, and $8 \%$ of the study area respectively. An ANOVA indicated that the mean 2000 TCA values for these three classes differed significantly $(\alpha=0.05, \mathrm{~d} f=2$, $p$-value $<0.05)$. Figure 3 illustrates the mean trajectory of TCA values for a sample of forest stands that were disturbed in 1978, 2001, and 2008. All of these examples represent dense coniferous forest stands that experienced some form of stand replacing disturbance (with the Landsat imagery having been acquired post-disturbance, but in

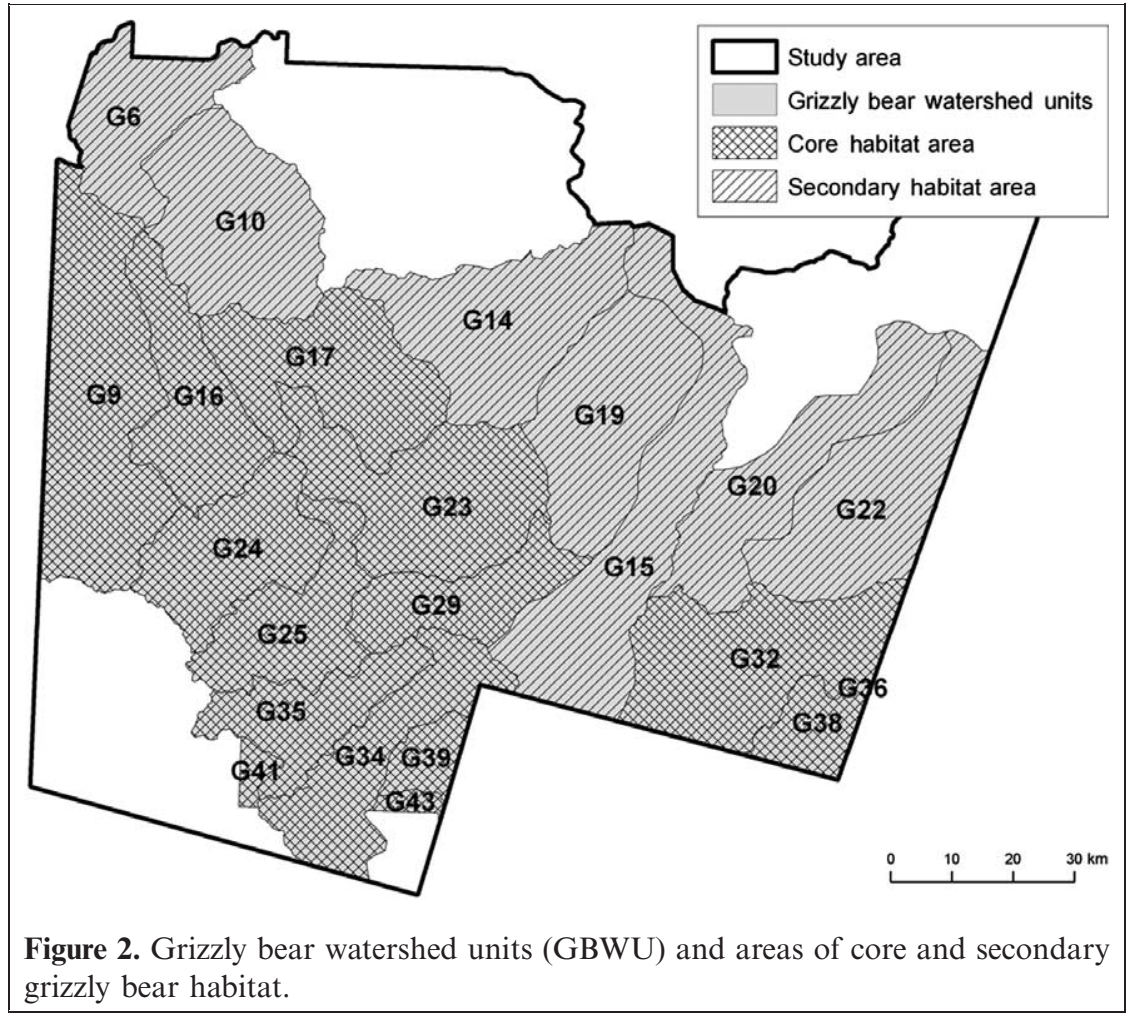




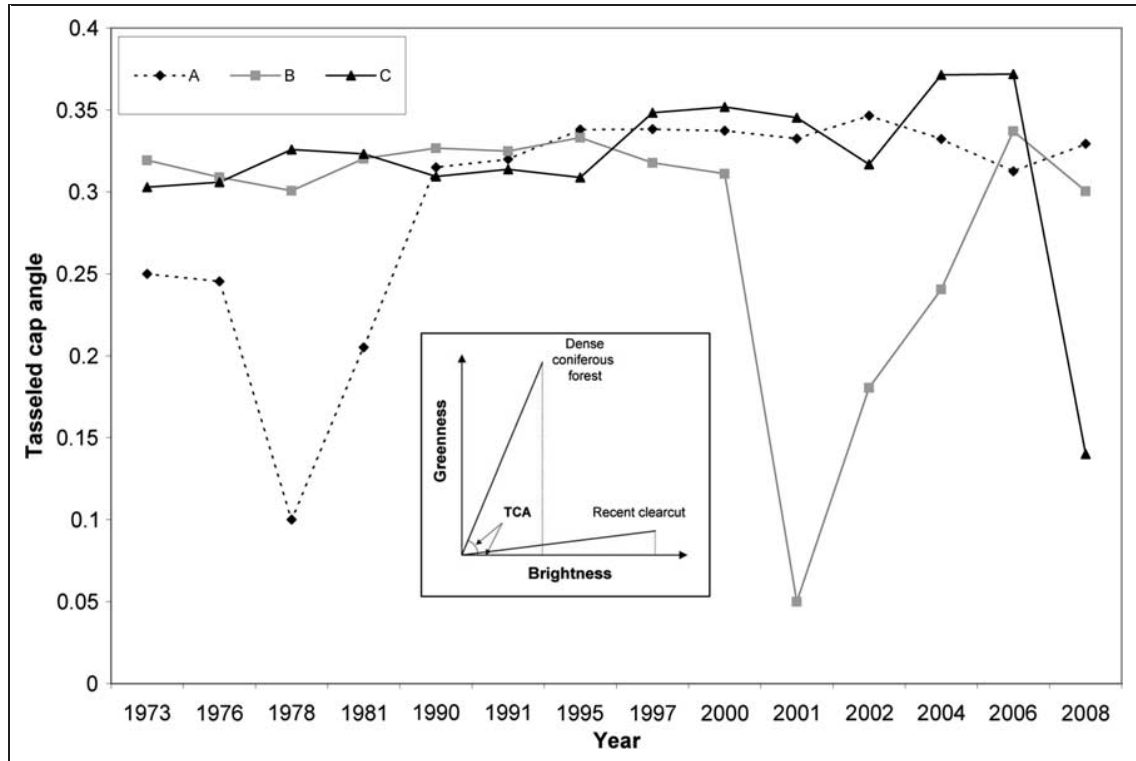

Figure 3. The Tasseled Cap Angle (TCA) is based on the premise that densely vegetated areas will have higher greenness and lower brightness than non-vegetated areas (inset). Mean TCA trajectories are shown for a sample of forested stands that were disturbed in 1978 (A), 2001 (B), and 2008 (C). A decrease in the TCA is expected in the image that is acquired post-disturbance.

the same year as the disturbance event). As expected, TCA values decrease markedly following the disturbance, and then experience a return to their predisturbance values (or greater) within 5-10 years.

\section{Change detection}

From the Landsat image time series, it was determined that approximately $1488 \mathrm{~km}^{2}$ or $11 \%$ of the analysis area experi- enced some form of stand-replacing disturbance between 1973 and 2008 (Figure 4). The greatest proportion of this change (by area) occurred between 2004 and 2006 (24\%), while the lowest proportion occurred between 2000 and 2001 $(2 \%)$. The number of change events fluctuated over time, with a maximum of 36623 change events in the period between 2004 and 2006 (representing 29\% of all change events between 1973 and 2008) and a minimum of 2888 change events between 1976 and 1978 (Figure 5). The mean change event

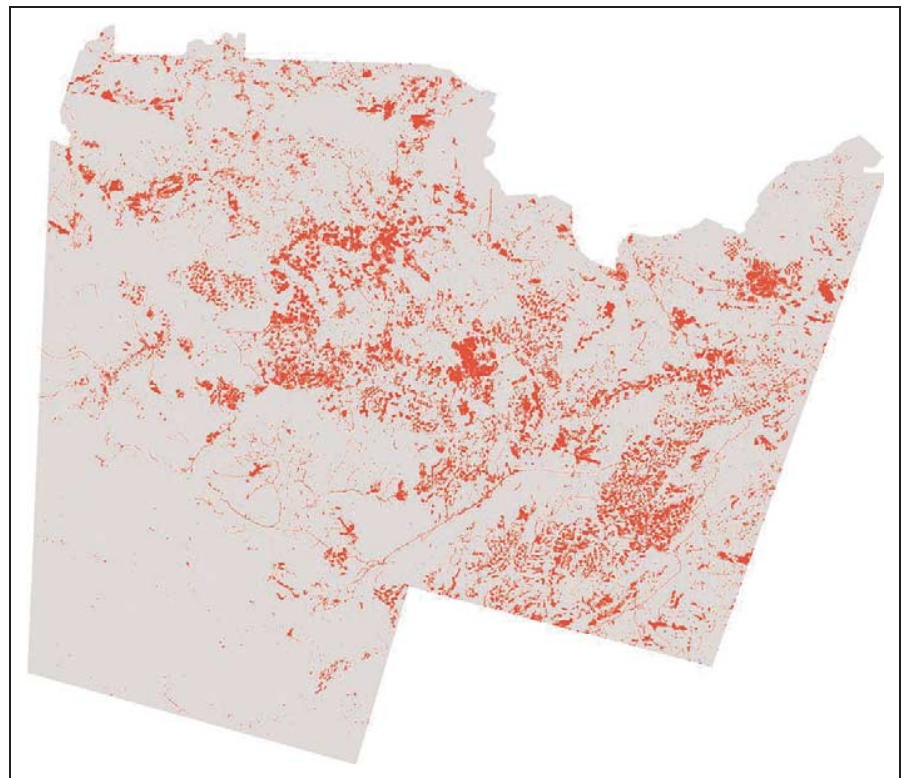

Figure 4. Change events occurring in the study area between 1973 and 2008, as captured by the Landsat image time series. 


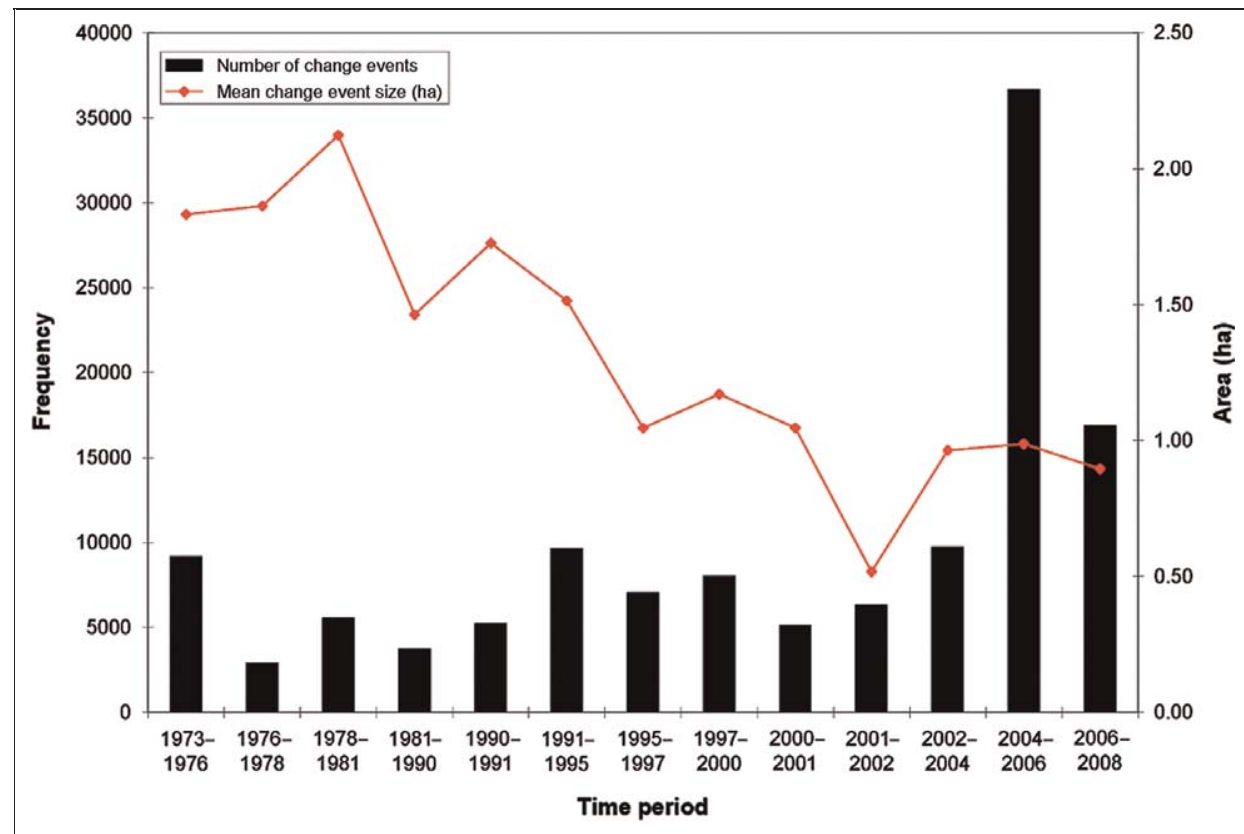

Figure 5. Number and mean size of change events, by time period.

size decreased over time, typically being greater than 1.5 ha pre-1995 and less than 1.5 ha post-1995 (Figure 5). Using Puyravaud's (2003) formula, the annual rate of land cover change, by decade, increased over time from a low of $-0.04 \%$ in the 1980 s to a high of $-0.48 \%$ in the 2000 s (during which time $46 \%$ of all changes occurred by area) (Figure 6). When the annual rate of change is calculated for individual time periods however, the annual rate of change is more variable, with a minimum of $-0.04 \%$ in $1981-1990$ and a maximum of $-1.25 \%$ in 2004-2006 (Figure 7).
Approximately $8.4 \%$ of core habitat areas and $13.7 \%$ of secondary habitat areas experienced some form of standreplacing disturbance between 1973 and 2008. The greatest proportion of this change (by area) occurred between 2004 and 2006 in both core $(2.06 \%)$ and secondary $(2.78 \%)$ habitat areas. Variation in the annual rate of land cover change was similar for both core and secondary habitat areas, with the latter having a greater rate of change prior to 1981 (Figure 8).

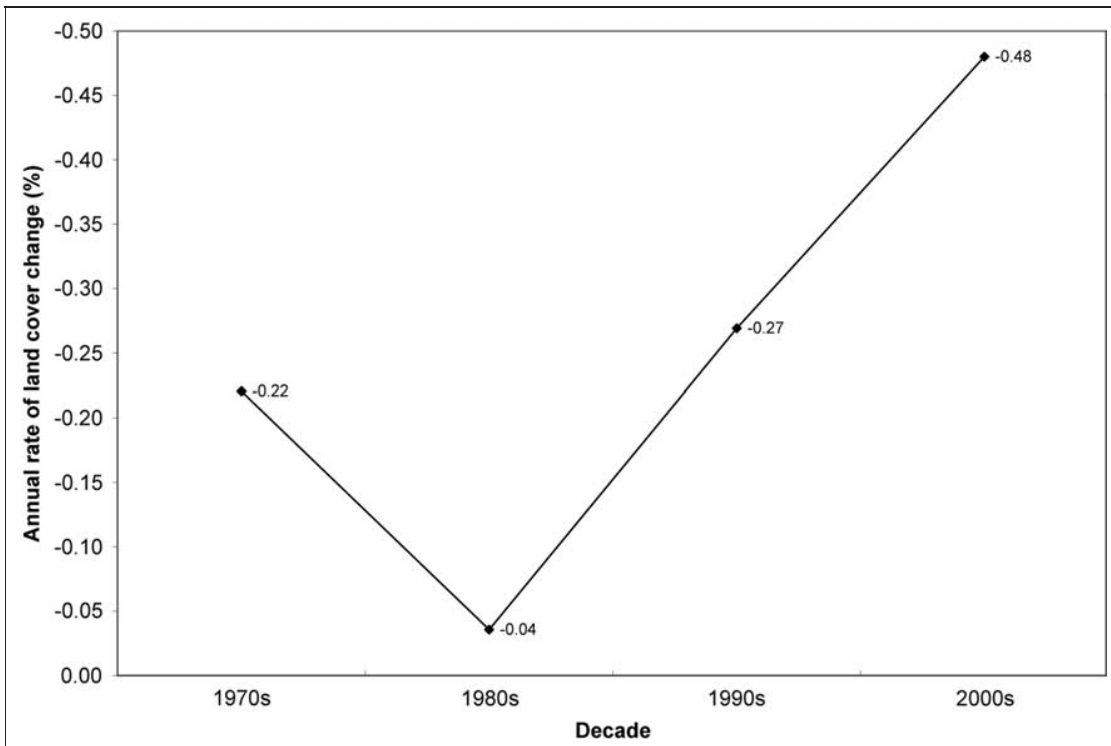

Figure 6. Annual rate of land cover change, by decade, calculated using Puyravaud's formula (Puyravaud, 2003). The rate of change is interpreted as the rate at which areas without change are converted to areas with change; areas without change are either increasing $(+)$ or decreasing $(-)$. 


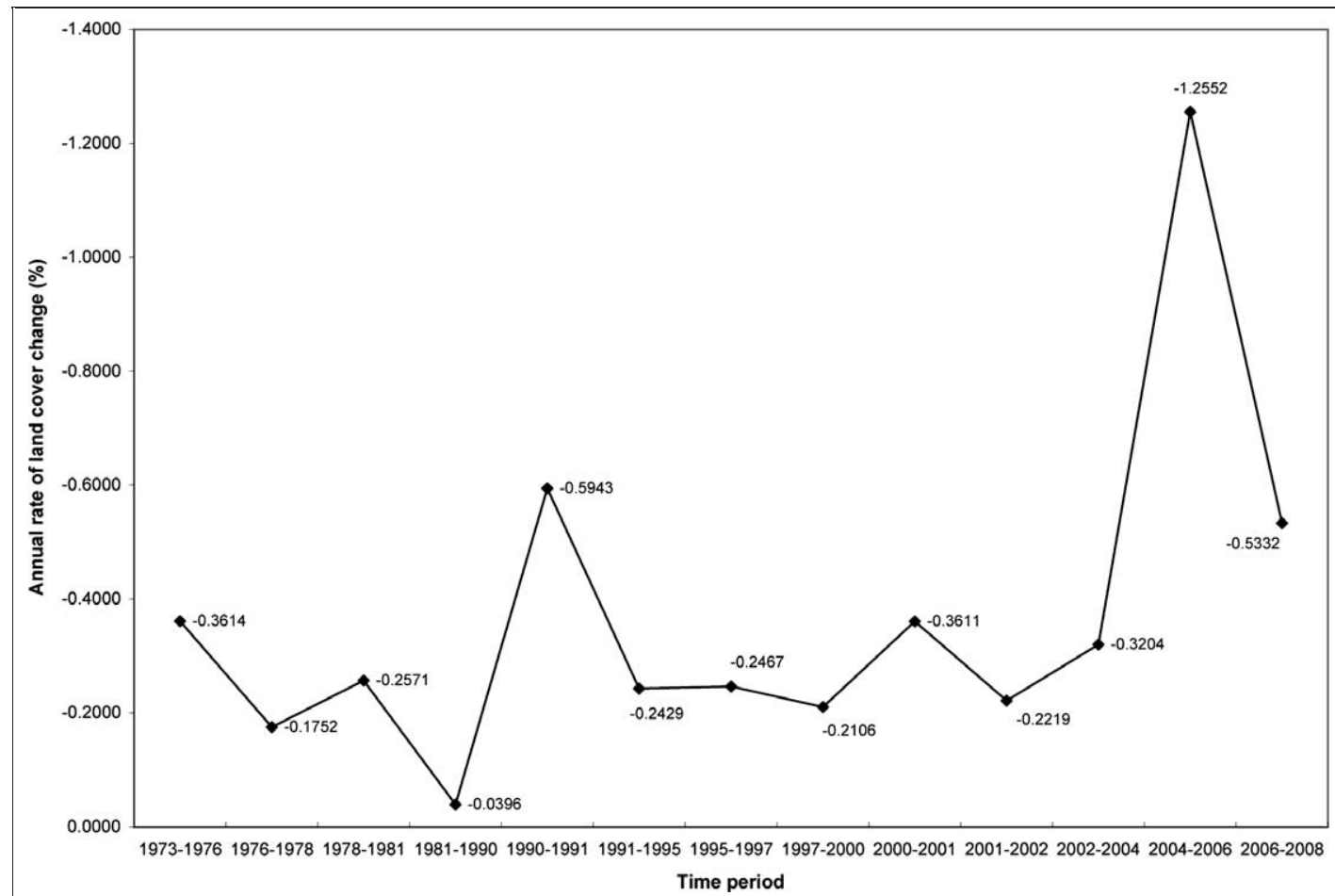

Figure 7. Annual rate of land cover change, by time period, calculated using Puyravaud's formula (Puyravaud, 2003). The rate of change is interpreted as the rate at which areas without change are converted to areas with change; areas without change are either increasing $(+)$ or decreasing $(-)$.

Within each of the GBWUs, the amount and rate of change was not uniform: the amount of area that changed between 1973 and 2008 ranged from $1.83 \%$ in G25 to $20.40 \%$ in G19. The GBWUs in the southwest of the study area (Figure 2), experienced the lowest proportion of change. Figure 9 compares the median annual change rate for each GBWU (1973-2008) to the 2008 road density within the GBWU (Statistics Canada, 2008). As indicated in Figure 9, the median

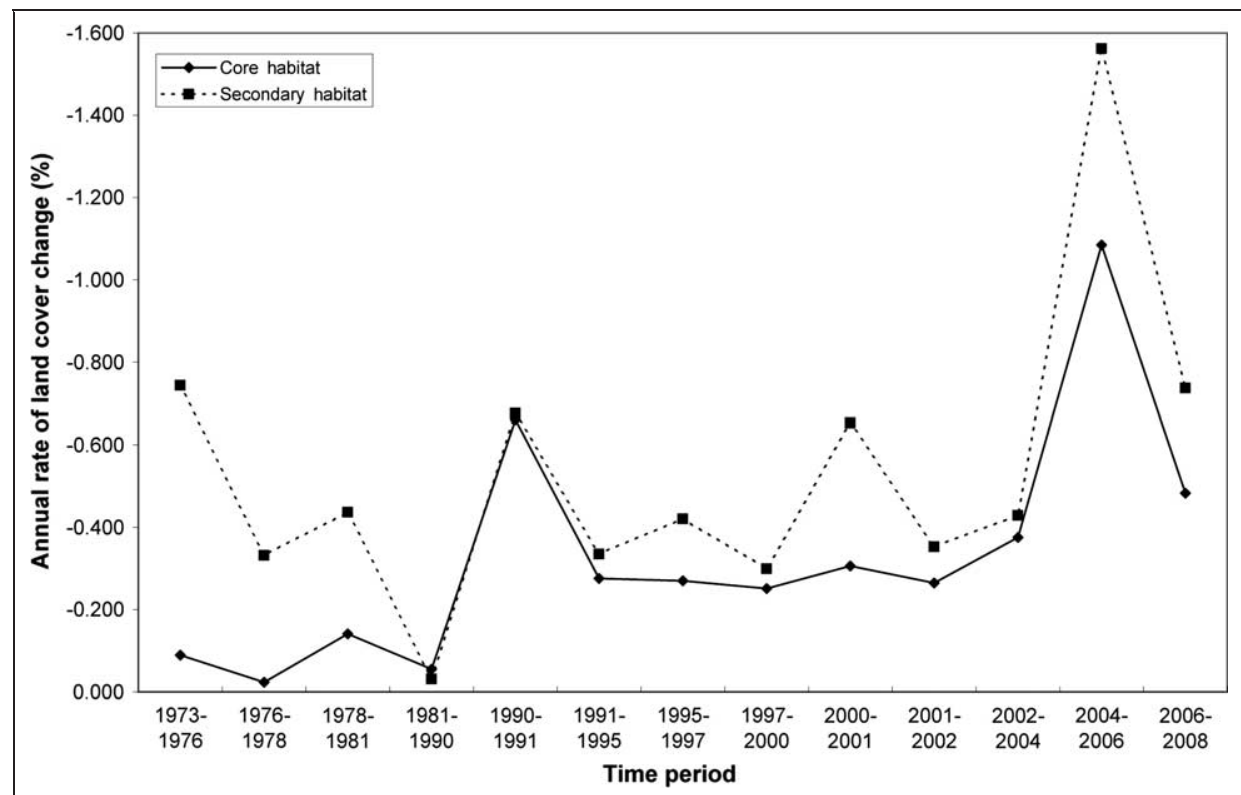

Figure 8. Annual rate of land cover change for grizzly bear core and secondary habitat areas (Puyravaud, 2003). The rate of change is interpreted as the rate at which areas without change are converted to areas with change; areas without change are either increasing $(+)$ or decreasing ( - ). 


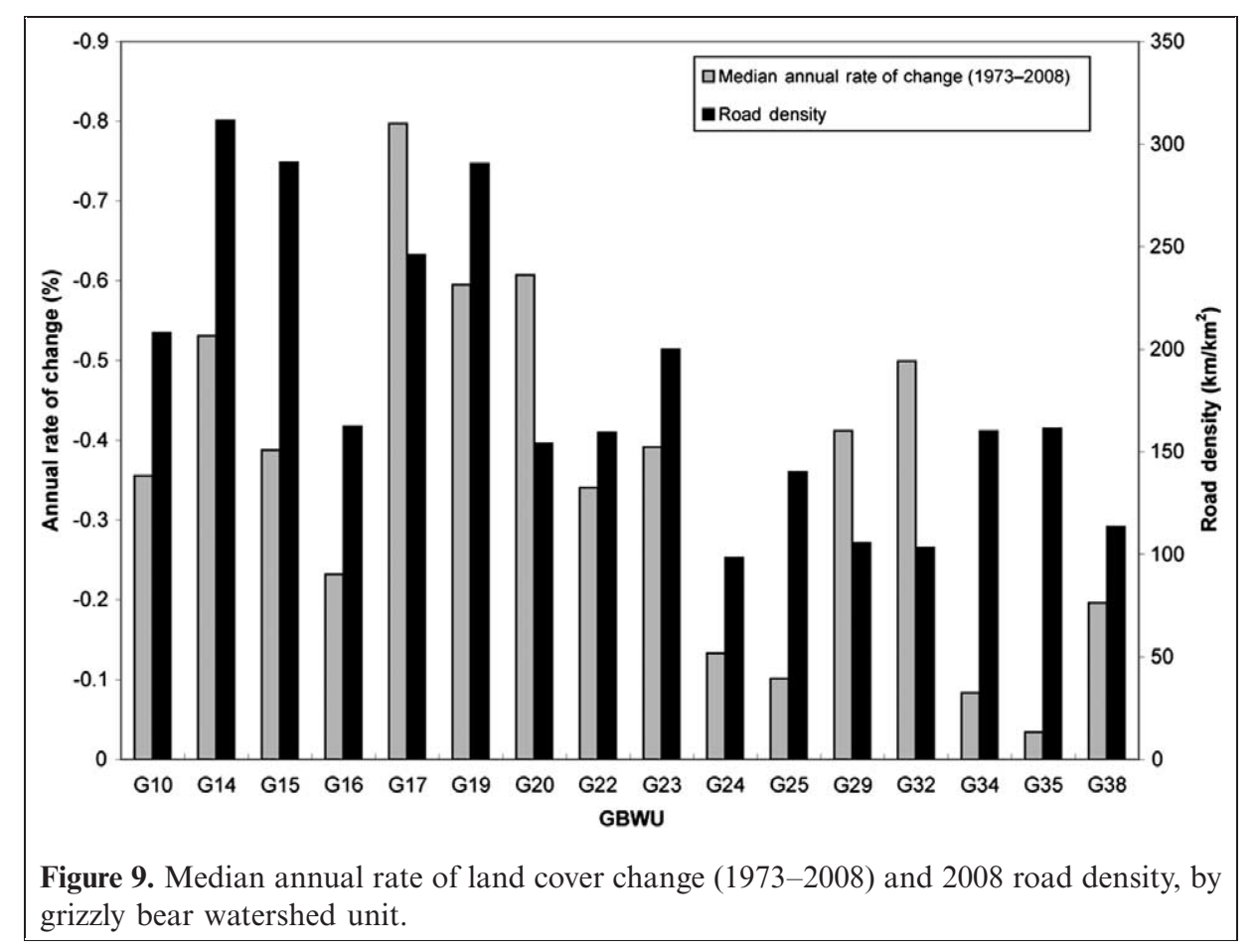

annual rate of land cover change was greatest in GBWU G17 (core habitat) and lowest in G35, while road density was greatest in G14 (secondary habitat) and lowest in G24.

\section{Comparison with reference data}

Figure 10 indicates the magnitude of the differences between the Landsat annual rates of change and the reference data annual rates of change by time period. Recall that the values were computed by the following formula: [(reference_rate - Landsat_rate)/reference_rate]. The values are expressed as percentages. Values above the zero indicate that the Landsat rate of change is less than that found from the reference data. Compared with the reference source, Landsat produced a lower annual rate of change in core habitat areas for all time periods except

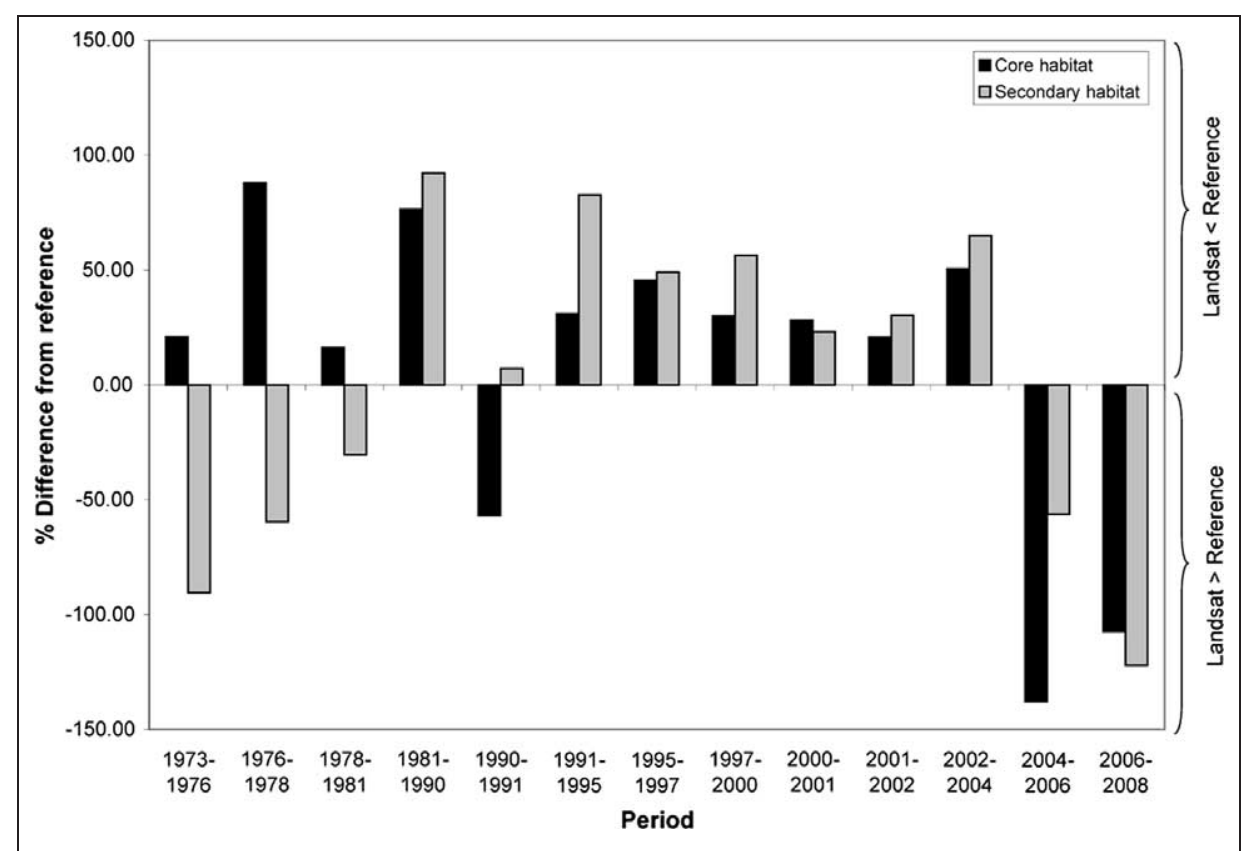

Figure 10. Comparison of the Landsat-derived annual rates of change to the reference annual rates of change, by core and secondary habitat types. 
1990-1991, 2004-2006, and 2006-2008. Conversely, as indicated by values below the zero line, Landsat produced a greater annual rate of change in areas of secondary habitat for pre-1981 and post-2004 periods. For the GBWUs, the reference data estimates greater annual rates of change in 9 of the 16 GBWUs (Figure 11). The greatest differences in the estimates of annual rates of change are for G14, G16, G17, and G22.

\section{Discussion}

\section{The TCA}

The TCT components have been used extensively in forest change detection studies (e.g., Skakun et al., 2003; Healey et al., 2005; Hilker et al., 2009; Hais et al., 2009). The TCA is a relatively new TCT data structure, first presented by Powell et al. (2010) as a predictor variable for aboveground tree biomass. Expressed as a single band per image date, the TCA is based on the premise that vegetated areas will have higher greenness and lower brightness values than nonvegetated areas (Figure 3). Differencing of TCA values for two image dates identifies those areas where changes in vegetation cover have occurred, with the sensitivity-or the amount/type of change - sought dictating threshold development and identification. Since all Landsat sensors have the requisite bands to generate the greenness and brightness components, the TCA is particularly well suited to longterm change detection studies that include MSS data (Powell et al., 2010). Although additional testing of the TCA is likely required, the results of this study indicate that the TCA fulfills the four criteria identified by Healey et al. (2005) for the selection of data structures to characterize forest disturbance: it maximizes separability between change and no change, it is robust across a range of conditions, it has a consistent rate of signal decay, and it reduces redundant or unnecessary data.

\section{Change detection}

The Landsat image time series provided a 35-year record of the location, amount, and rate of change in the Kakwa study area. By assessing the change outputs using habitat types and management units, we are able to see the variation in the spatial distribution of change across the study area in a context that is meaningful to grizzly bear management.

The decrease in the mean size of change events suggests that the nature of activities in the study area has evolved over time, with events of a smaller mean size, such as oil and gas well sites and smaller cutblocks, becoming more prevalent post-2000. The reference data indicates a similar trend, with cutblocks as the dominant change event prior to 2000, and oil and gas development increasing after 2000 (Figure 12). Independent data confirms that the number of oil and gas well sites drilled within forest ecozones in Alberta has increased dramatically since 2000: of the 212528 wells that have been drilled in the province since $1908,41 \%$ of these have been drilled since 2000 (Lee et al., 2009a, 2009b).

Changes in the size of forest cutblocks are likely also a factor: between 1970 and 1995, the average cutblock size in Alberta varied. Cutblocks for coniferous species ranged from a low of 10.9 ha in 1970 to a high of 24.2 ha in 1983; cutblocks for deciduous species range from a low of 13.2 ha in 1977 to a high of 46.0 ha in 1983. The average cutblock size for both deciduous and coniferous species was approximately 20 ha in 1995. The trend in Alberta (as in most other jurisdictions in Canada) has been towards smaller cutblocks (Alberta Environment, 2001); however, many smaller cutblocks that extend over a larger area will require more active

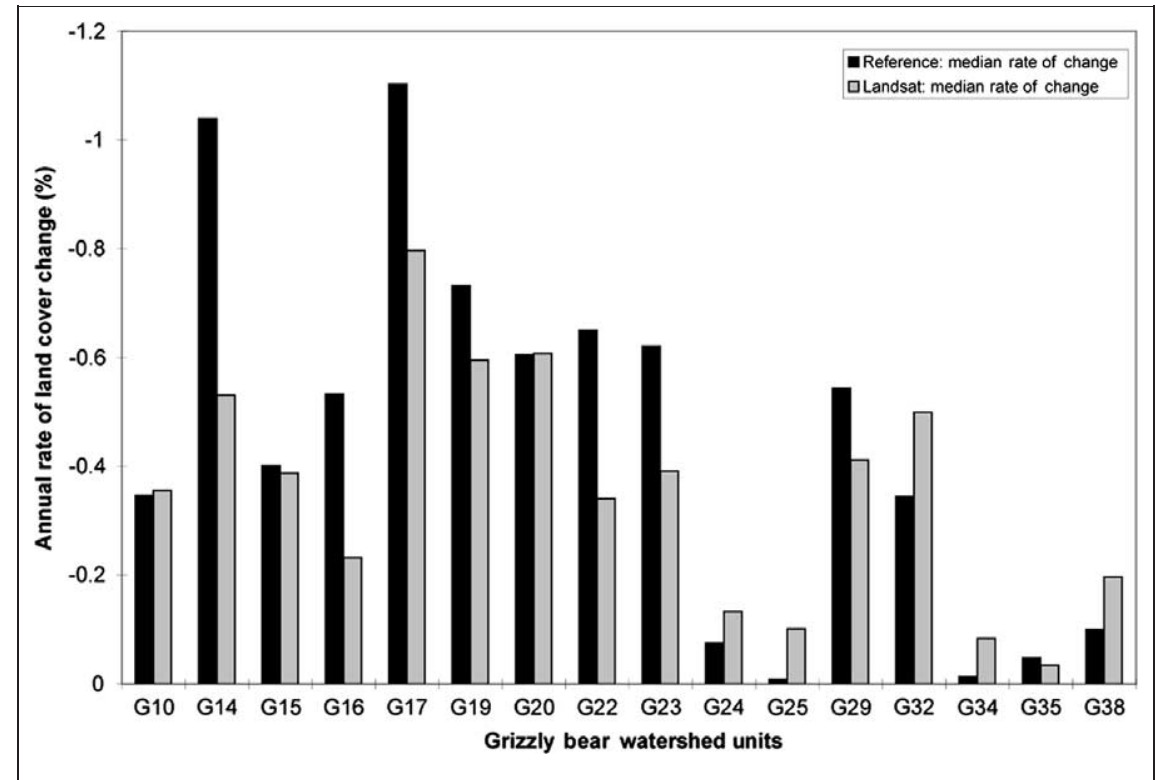

Figure 11. Median annual rates of land cover change, by grizzly bear watershed unit. 


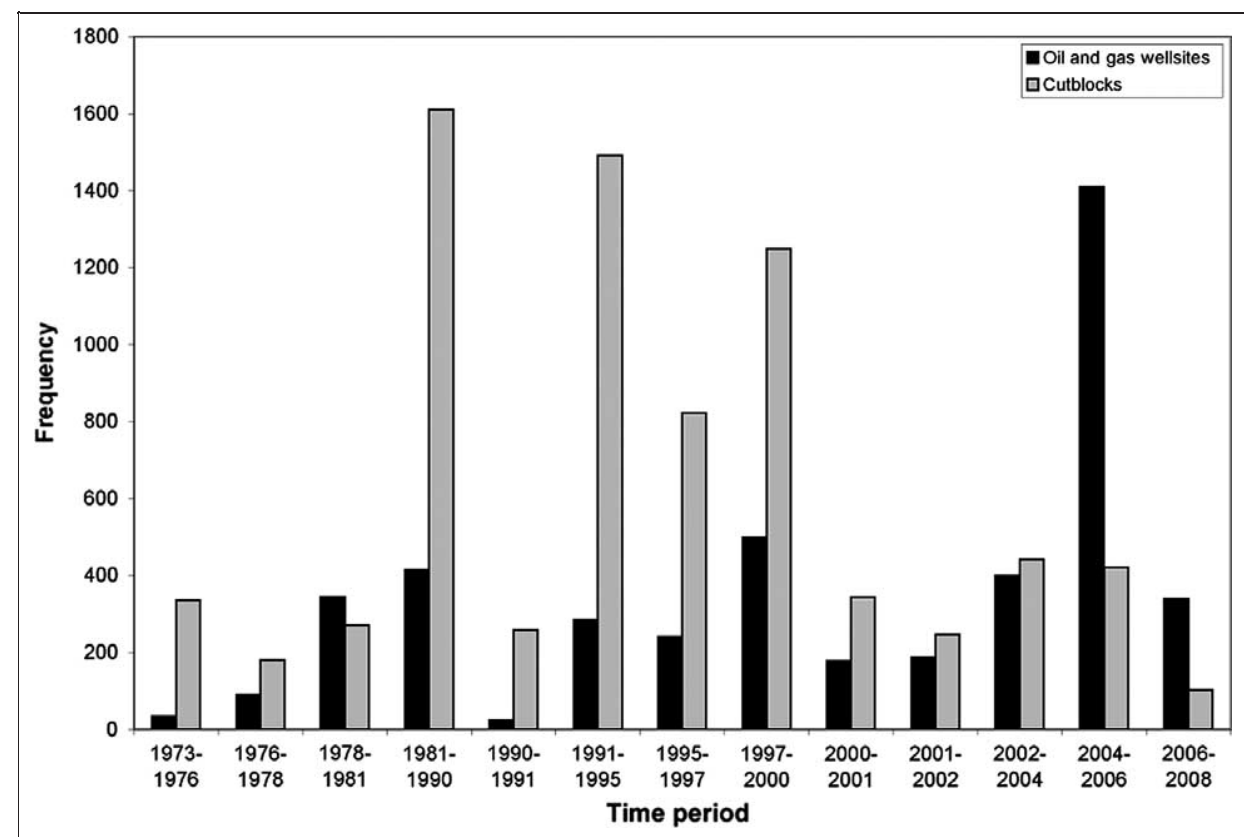

Figure 12. Reference data frequency for oil and gas wellsites and forest cutblocks, by time period.

roads for access than would fewer, larger clearcuts (Clayoquot Sound Scientific Panel, 1995, p.58): "For a given level of timber harvest, many dispersed, small cutblocks usually extend over a greater proportion of a watershed and require longer distances of active road than do fewer, larger clearcuts. When clearcutting is the system of choice and roads are used for log transport, patterns created by dispersed, small cutblocks are more harmful to water regimes and to some vertebrate species than are those created by fewer, larger clearcuts of the same total area." Since the smaller cutblock approach usually results in an increase in open road densities, and increased road densities have been related to reduction in survival rates in grizzly bear populations (Stenhouse et al., 2005), this forest management strategy can be expected to negatively influence grizzly bear populations.

Roads are typically associated with anthropogenic disturbances and road density has been used as an indicator of forest fragmentation (Heilman et al., 2002; Riitters and Wickham, 2003). Since not all roads are detectable with the spatial resolution of Landsat imagery, it is interesting to compare road density (derived from an independent data source) within each GBWU to annual rates of change. It is important to note that depending on terrain, some GBWU may be conduits for road access into a region (e.g., G14), while actual disturbances are concentrated in other units (e.g., G17).

Anthropogenic infrastructure such as roads, cut-lines, seismic lines, and pipelines affect landscapes in a multitude of ways. For example, these linear features can increase the amount of edge habitat, disrupt hydrological regimes, alter ecological processes, increase wildlife mortality, enable human access for hunting and other uses, and result in landscape fragmentation and soil compaction (e.g., Vaisanen et al., 1986; Roland, 1993; Hobson and Bayne, 2000; Kuri et al., 2000; Patriquin and Barclay, 2003; Schneider, et al., 2003; Nielsen et al., 2004a). Furthermore, linear features can serve as wildlife corridors, altering predator-prey dynamics and enabling the introduction of new species to an area (e.g., McLellan and Shackleton, 1988; Fleming and Schmiegelow, 2003; Oberg et al., 2003; Merrill et al., 2005). The cumulative effects of these resource extraction activities pose a challenge for resource managers and have resulted in alterations to the forest land base, an increase in human access, and a forest that is both younger and more fragmented than it was previously (Schneider et al., 2003).

Scrimgeour et al. (2003) examined the cumulative effects of watershed disturbances on stream fish communities in the Kakwa and Simonette watersheds, both of which are located predominantly within our study area (Figure 13). For their study, Scrimgeour et al. (2003) compiled an extensive GIS database containing information on forest harvesting and the development of oil and gas well sites, various industrial facilities, roads, seismic lines, power lines, pipelines, and railway lines. From this data, they quantified the proportion of each watershed that was disturbed, concluding that approximately $10.2 \%$ of the Kakwa watershed and $18.7 \%$ of the Simonette watershed were disturbed. The majority of anthropogenic disturbances in both watersheds, by area, were from forest harvesting (84\%), far exceeding that of roads, seismic lines, and oil and gas well sites. Alberta's forest industry expanded significantly in the mid-1980s and the majority of changes in our study area $(77 \%)$ occurred post-1980. Scrimgeour et al. (2003) also found that the 


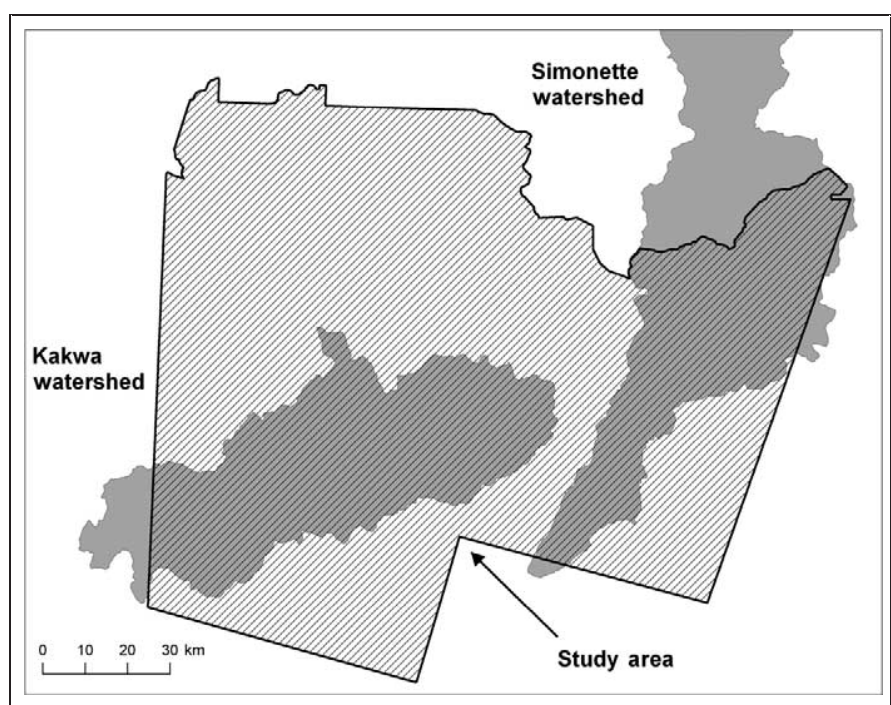

Figure 13. Location of the Kakwa and Simonette watersheds (Scrimgeour et al., 2003).

density of roads, seismic lines, and oil and gas well sites in the Simonette watershed was double that of the Kakwa watershed. The findings of Scrimgeour et al. $(2003,2008)$ corroborate the trends derived from the Landsat image time series used in this study, particularly the greater concentra- tion of disturbance in the eastern portion of the study area (Simonette watershed) relative to the western portion (Kakwa watershed). It is also interesting to consider the variation in the amount of change per time period in the context of the wellhead price for natural gas (Figure 14). Natural gas wellhead prices have increased dramatically from 0.22 USD per $1000 \mathrm{ft}^{3}$ in 1973 to a maximum of 7.96 USD per $1000 \mathrm{ft}^{3}$ in 2008 and these increasing prices have no doubt led to increased exploration and development of natural gas reserves in the area.

Population surveys have indicated that the Grande Cache Bear Management Area (within which our study area is located) has the largest population of grizzly bears in any of the management areas surveyed to date (Alberta Grizzly Bear Inventory Team, 2009). Analyses have also indicated that in all other grizzly bear management areas in Alberta, there is a clear relationship between high road densities and a low presence of grizzly bears; however, in the Kakwa area this is not the case: despite the high road densities in the area, there is still a large number of bears. This may be result of the relatively recent and rapid nature of landscape change in this area, as well as the juxtaposition of this area relative to Kakwa and Willmore protected areas and Jasper National Park. It is also possible that the high density of ungulates in the study area may be influencing reproductive performance of this bear population. It is noteworthy that

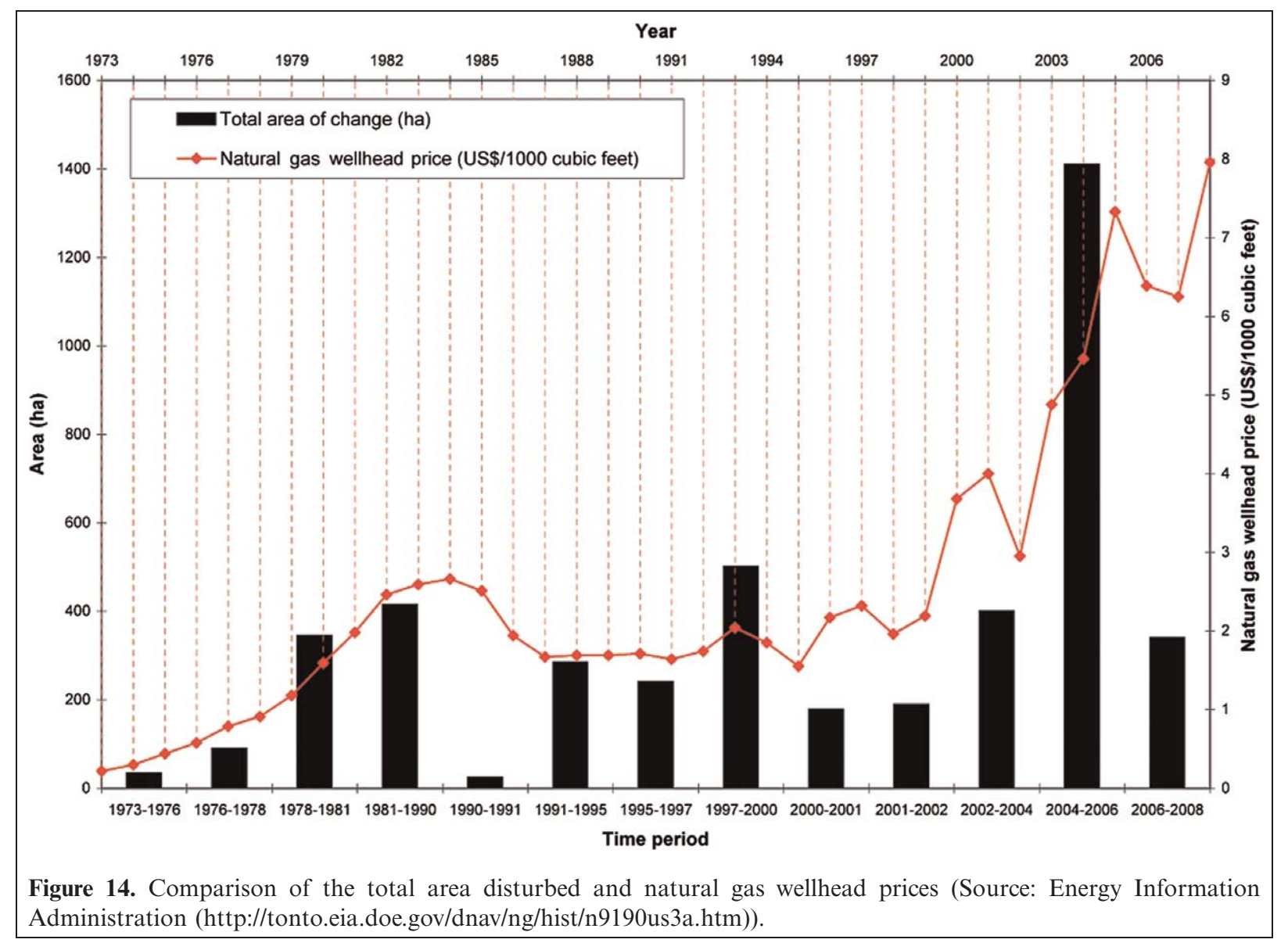


prior to the closure of sport hunting in 2006, the majority of hunting mortality in recent years has occurred in the Grande Cache unit (48\% of the total legal harvest between 1998 and 2002) (Festa-Bianchet, 2010). Grizzly bears can live to an age of 28 to 30 years, and in an area that does not have a long history of landscape change, human-caused grizzly bear mortality may be quite low. Furthermore, in the short term, recent landscape changes may have improved and (or) increased prey densities and foraging opportunities, thereby increasing the area's carrying capacity for grizzly bears. In other areas of Alberta, intense landscape change has been ongoing for a longer period of time (Festa-Bianchet, 2010). Ongoing monitoring of the grizzly population in the Grande Cache Bear Management Area will be required to determine the longer-term impacts of the recent landscape changes in the study area identified using the Landsat time series.

\section{Comparison to reference data}

The lack of suitable cloud-free Landsat imagery between 1980 and 1991 in this area is problematic for our estimation of change. A biennial image interval is considered preferable for change detection in order to minimize omission errors in detection of disturbances (although this may be more of an issue in areas where trees grow rapidly and green-up can make change detection difficult, such as in the tropics) (Huang et al., 2009). Figure 3 illustrates that even in the northern forest of our study area, TCA values can return to their pre-disturbance level within 5-10 years. The reference data indicate that forest harvesting peaked between 1980 and 1991 (Figure 12), yet the Landsat annual rate of change was at a minimum in this same period (Figure 7). Alternatively, oil and gas development peaked during 2004-2006 (Figure 12), and the density of images in our time series from 2000-2008 (Table 1) allowed us to capture this trend (Figure 7). In recent years when oil and gas exploration have increased, it is expected that Landsat rates of change will exceed those of the inventory and photo-based reference data (see recent epochs in Figure 10). Seismic lines, well sites, and associated road construction, are not as readily captured in common reference datasets but are captured in satellite change detection. Landsat rates can be expected to be less than reference data rates when the image pair of a particular epoch is of a longer duration. The regeneration that can occur over a multiple year period, e.g., the 1981-1990 epoch, results in increased difficulty to confidently find change based upon an understanding of diminishing detectability of change over time (Wulder et al., 2005). Differences in the rates of change over time between the imagery and the reference data can be understood in a number of ways. Readers should recall that the image-based change detection and calculation of rates are produced in a consistent, manually-assisted (threshold determination) automated approach in a spatially exhaustive fashion over the entire study area. Key difficulties were in obtaining imagery for historic time intervals, resulting in epochs of differing length and possible omission of changes due to regeneration. The reference data are not spatially exhaustive and are only updated periodically where there is information (i.e., photography, silvicultural records) to support an inventory revision.

Obtaining independent reference information with sufficient temporal frequency for validation of change maps is complicated ( $\mathrm{Lu}$ et al., 2004; Cohen et al., 2010). For locations with aerial photography we could readily corroborate the spatial location of change events, but the exact time of occurrence was more complicated, especially when the time step of our series of images differed markedly from the reference data. The decadal frequency of typical inventory or field data is insufficient for validation of image-based, dense time series, change maps. Further, more work is needed in developing methods for evaluation of historical change accuracy. Some strategies incorporating high spatial resolution imagery are emerging, like the TimeSync tool from Cohen et al. (2010), which incorporates imagery from GoogleEarth. Although this is an invaluable source of data, GoogleEarth imagery is only available for a short historic period and with variability in the nature of the imagery present. In the case of this study area, Landsat and SPOT imagery are the primary data sources currently present in GoogleEarth.

\section{Wide-area implementation considerations}

In this research, we focused on a single Landsat scene. To produce a similar dense time series representative of a wide area, multiple neighbouring scenes must be acquired and additional considerations must be made. The image availability for each scene location is unlikely to be the same, resulting in different epochs for each time series. Producing rates of change for each scene may mitigate the use of imagery from different dates to produce the time series. Phenologic and radiometric considerations may also emerge as issues when attempting to extend time series analysis spatially. For example, images from different seasons may result in spurious changes being detected because of differences in season and plant growth stage. Sun-surfacesensor geometry will also result in differing spectral manifestations based upon the local forest structure, which could also result in unexplained changes. Gaulton et al. (2011) have undertaken a wide-area change detection approach based on image fusion whereby MODIS imagery can normalize spatially across scenes. The use of MODIS imagery results is an approach that may be applicable for year 2000 forward, but may not be helpful for earlier years. A key decision will be whether to work on a scene-by-scene basis and perform the aggregation on the outcomes or to attempt to normalize across scenes spatially and attempt to perform analyses on the mosaics produced. The compositing 
logic presented by Roy et al. (2008) provides insights on how the latter (mosaic based) option may be implemented.

\section{Conclusion}

Landsat time series data can provide retrospective information on the location, extent, and rate of natural and anthropogenic forest disturbances. Such information is useful as inputs for modeling of grizzly bear distribution, abundance, survival, and health. Since the existence and documentation of land cover change information from conventional sources such as fieldwork or inventory data are either temporally or spatially limited, one of the primary advantages of a remotely sensed image time series is the consistency with which disturbance events can be identified and captured across large areas. The recent public release of the Landsat image archive affords a new opportunity for lengthy time series analyses of land cover change. Such analyses can inform on how historic changes have influenced the current state of species at risk, as well as characterizing the impact of management practices over time. In this study, 35 years of landscape change in an area of grizzly bear habitat have been documented and characterized. A key outcome is the capacity to better understand how historic dynamics, not just current conditions, influence habitat use by grizzly bears. Future research will examine the link between these remotely sensed outputs and models of grizzly bear distribution, abundance, survival, and health.

\section{Acknowledgements}

This research was undertaken as part of the "BioSpace: Biodiversity monitoring with Earth Observation data" project, jointly funded by the Canadian Space Agency (CSA) Government Related Initiatives Program (GRIP), and the Canadian Forest Service (CFS) of Natural Resources Canada. Additional support of this research was generously provided by the Grizzly Bear Program of the Foothills Research Institute located in Hinton, Alberta, Canada, with additional information available at http:// www.foothillsresearchinstitute.ab.ca.

\section{References}

Alberta Environment. 2001. Alberta 1997 State of the Environment Report: Terrestrial Ecosystems. Alberta Environment, Calgary, Alberta. Available online: http://www.assembly.ab.ca/lao/library/egovdocs/alen/1997/ 132401_97.pdf [cited September 1, 2010].

Alberta Grizzly Bear Inventory Team. 2009. Grizzly bear population and density estimates for the 2008 DNA inventory of the Grande Cache Bear Management Area (BMA 2). Available online: http://www.srd.alberta. $\mathrm{ca} /$ ManagingPrograms/FishWildlifeManagement/BearManagement/ documents/GrizzlyBear-DNAPopulationEstimate2008-Jul7-2009.pdf [cited September 1, 2010].
Alberta Sustainable Resource Development. 2009. Annual Report 2008/ 2009. Alberta Sustainable Resource Development, Edmonton, Alberta, Canada.

Andison, D.W. 1998. Temporal patterns of age-class distributions on foothills landscapes in Alberta. Ecography, Vol. 21, No. 5, pp. 543550 .

Apps, C.D., McLellan, B.N., Woods, J.G., and Proctor, M.F. 2004. Estimating grizzly bear distribution and abundance relative to habitat and human influence. The Journal of Wildife Management, Vol. 68, No. 1, pp. 138-152. doi: 10.2193/0022-541X(2004)068[0138:EGBDAA] 2.0.CO;2.

Benn, B., and Herrero, S. 2002. Grizzly bear mortality and human access in Banff and Yoho National Parks, 1971-98. Ursus, Vol. 13, pp. 213221.

Bergen, K.M., Zhao, T., Kharuk, V., Blam, Y., Brown, D.G., Peterson, L.K., and Miller, N. 2008. Changing regimes: Forested land cover dynamics in central Siberia 1974 to 2001. Photogrammetric Engineering and Remote Sensing, Vol. 74, No. 6, pp. 787-798.

Berland, A., Nelson, T., Stenhouse, G., Graham, K., and Cranston, J. 2008. The impact of landscape disturbance on grizzly bear habitat use in the Foothills Model Forest, Alberta, Canada. Forest Ecology and Management, Vol. 256, No. 11, pp. 1875-1883. doi: 10.1016/j.foreco. 2008.07.019.

Boone, R.B., and Hunter, M.L. 1996. Using diffusion models to simulate the effects of land use on grizzly bear dispersal in the Rocky Mountains. Landscape Ecology, Vol. 11, No. 1, pp. 51-64.

Boyce, M.S., Nielsen, S.E., and Stenhouse, G.B. 2009. Grizzly bears benefit from forestry-except for the roads. BC Forest Professional. JanuaryFebruary, p. 19.

Canty, M.J., Nielsen, A.A., and Schmidt, M. 2004. Automatic radiometric normalization of multitemporal satellite imagery. Remote Sensing of Environment, Vol. 91, No. 3-4, pp. 441-551. doi: 10.1016/j.rse.2003. 10.024 .

Chander, G., Markham, B.L., and Helder, D.L. 2009. Summary of current radiometric calibration coefficients for Landsat MSS, TM, ETM +, and EO-1 ALI sensors. Remote Sensing of Environment, Vol. 113, No. 5, pp. 893-903. doi: 10.1016/j.rse.2009.01.007.

Clayoquot Sound Scientific Panel. 1995. Sustainable Ecosystem Management in Clayoquot Sound: Planning and Practices. Report Number 5. Available online: http://www.cortex.org/Rep5c1-2.pdf [accessed 2 September 2010].

Cohen, W.B., Spies, T.A., and Fiorella, M. 1995. Estimating the age and structure of forests in a multi-ownership landscape of western Oregon, U.S.A. International Journal of Remote Sensing, Vol. 16, pp. 721-746. doi: $10.1080 / 01431169508954436$.

Cohen, W.B., Fiorella, M., Gray, J., Helmer, E., and Anderson, K. 1998. An efficient and accurate method for mapping forest clearcuts in the Pacific Northwest using Landsat imagery. Photogrammetric Engineering \& Remote Sensing, Vol. 64, pp. 293-300.

Cohen, W.B., and Goward, S. 2004. Landsat's role in ecological applications of remote sensing. BioScience, Vol. 54, pp. 535-545. doi: 10.1641/ 0006-3568(2004)054[0535:LRIEAO]2.0.CO;2.

Cohen, W.B., Yang, Z., and Kennedy, R. 2010. Detecting trends in forest disturbance and recovery using yearly Landsat time series: 2. TimeSyncTools for calibration and validation. Remote Sensing of Environment, Vol. 114, pp. 2911-2924. doi: 10.1016/j.rse.2010.07.010. 
Coppin, P., Jonckheere, I., Nackaerts, K., and Muys, B. 2004. Digital change detection methods in ecosystem monitoring: A review. International Journal of Remote Sensing, Vol. 25, No. 9, pp. 15651596. doi: 10.1080/0143116031000101675.

Crist, E., and Kauth, R. 1986. The tasseled cap de-mystified. Photogrammetric Engineering and Remote Sensing, Vol. 52, No. 1, pp. $81-86$.

Crist, E.P., and Cicone, R.C. 1984. A physically based transformation of Thematic Mapper data - the TM Tasseled Cap. IEEE Transactions on Geoscience and Remote Sensing, Vol. GE-22, pp. 256-263. doi: 10.1109/ TGRS.1984.350619.

Festa-Bianchet, M. 2010. Status of the grizzly bear (Ursus arctos) in Alberta: Update 2010. Alberta Wildlife Status Report No. 37 (Update 2010). Edmonton, Alberta. Alberta Sustainable Resource Development and Alberta Conservation Association. Available online: http://www.srd. alberta.ca/BioDiversityStewardship/SpeciesAtRisk/DetailedStatus/docum ents/Status-GrizzlyBear-inAlberta-Feb2010.pdf [cited September 2, 2010].

Foody, G.M. 2008. Harshness in image classification accuracy assessment. International Journal of Remote Sensing, Vol. 29, No. 11, pp. 3137-3158. doi: 10.1080/01431160701442120.

Foody, G.M. 2009. The impact of imperfect ground reference data on the accuracy of land cover change estimation. International Journal of Remote Sensing, Vol. 30, No. 12, pp. 3275-3281. doi: 10.1080/01431 160902755346.

Fleming, W.D., and Schmiegelow, F.K.A. 2003. Response of bird communities to pipeline rights-of-way in the boreal forest of Alberta. Proceedings from The Seventh International Symposium on Environmental Concerns in Rights-of-Way Management. pp. 431-437. Elsevier Science.

Gaulton, R., Hilker, T., Wulder, M.A., Coops, N.C., and Stenhouse, G. 2011. Characterizing stand replacing disturbance in western Alberta grizzly bear habitat, using a satellite-derived high temporal and spatial resolution change sequence. Forest Ecology and Management, Vol. 261, pp. 865-877. doi: http://dx.doi.org/10.1016/j.rse.2010.05.022.

Gillanders, S.N., Coops, N.C., Wulder, M.A., Gergel, S.E., and Nelson, T. 2008. Multitemporal remote sensing of landscape dynamics and pattern change: Describing natural and anthropogenic trends. Progress in Physical Geography, Vol. 35, No. 5, pp. 502-528. doi: 10.1177/ 0309133308098363.

Goodwin, N.R., Coops, N.C., Wulder, M.A., Gillanders, S., Schroeder, T.A., and Nelson, T. 2008. Estimation of insect infestation dynamics using a temporal sequence of Landsat data. Remote Sensing of Environment, Vol. 112, No. 9, pp. 3680-3689. doi: 10.1016/j.rse.2008. 05.005 .

Hais, M., Jonasova, M., Langhammer, J., and Kucera, T. 2009. Comparison of two types of forest disturbance using multitemporal Landsat TM/ ETM + imagery and field vegetation data. Remote Sensing of Environment, Vol. 113, No. 4, pp. 833-845. doi: 10.1016/j.rse.2008.12.012.

Han, T., Wulder, M.A., White, J.C., Coops, N.C., Alvarez, M.F., and Butson, C. 2007. An efficient protocol to process Landsat images for change detection with tasselled cap transformation. IEEE Geoscience and Remote Sensing Letters, Vol. 4, No. 1, pp. 147-151. doi: 10.1109/ LGRS.2006.887066.

Hansen, M.J., Franklin, S.E., Woudsma, C., and Peterson, M. 2001. Forest structure classification in the North Columbia mountains using Landsat TM tasseled cap wetness component. Canadian Journal of Remote Sensing, Vol. 27, pp. 20-32.
Healey, S.P., Cohen, W.B., Zhiqiang, Y., and Krankina, O. 2005. Comparison of tasseled cap-based Landsat data structures for forest disturbance detection. Remote Sensing of Environment, Vol. 97, No. 3, pp. 301-310. doi: 10.1016/j.rse.2005.05.009.

Healey, S.P., Yang, Z., Cohen, W.B., and Pierce, D.J. 2006. Application of two regression-based methods to estimate the effects of partial harvest on forest structure using Landsat data. Remote Sensing of Environment, Vol. 101, pp. 115-126. doi: 10.1016/j.rse.2005.12.006.

Heilman, G.E., Strittholt, J.R., Slosser, N.C., and Dellasala, D.D. 2002. Forest fragmentation of the conterminous United States: Assessing forest intactness through road density and spatial characteristics. BioScience, Vol. 52, No. 5, pp. 411-422. doi: 10.1641/0006-3568(2002) 052[0411:FFOTCU]2.0.CO;2.

Helmer, E.H., Brown, S., and Cohen, W.B. 2000. Mapping montane tropical successional stage and land use with multi-date Landsat imagery. International Journal of Remote Sensing, Vol. 21, pp. 2163-2183. doi: 10.1080/01431160050029495.

Hilker, T., Wulder, M.A., Coops, N.C., Linke, J., McDermid, G., Masek, J.G., Gao, F., and White, J.C. 2009. A new data fusion model for high spatial and temporal resolution mapping of forest disturbance based on Landsat and MODIS. Remote Sensing of Environment, Vol. 113, No. 8, pp. 1613-1627. doi: 10.1016/j.rse.2009.03.007.

Hobson, K.A., and Bayne, E. 2000. Effects of forest fragmentation by agriculture on avian communities in the southern boreal mixedwoods of western Canada. The Wilson Bulletin, Vol. 112, No. 3 pp. 373-387. doi: 10.1676/0043-5643(2000)112[0373:EOFFBA]2.0.CO;2.

Huang, C., Wylie, B., Yang, L., Homer, C., and Zylstra, G. 2002. Derivation of tasselled cap transformation based on Landsat 7 atsatellite reflectance. International Journal of Remote Sensing, Vol. 23, No. 8, pp. 1741-1748. doi: 10.1080/01431160110106113.

Huang, C., Goward, S.N., Schleeweis, K., Thomas, N., Masek, J.G., and Zhu, Z. 2009. Dynamics of national forests assessed using the Landsat record: Case studies in the eastern United States. Remote Sensing of Environment, Vol. 113, No. 7, pp. 1430-1442. doi: 10.1016/j.rse.2008. 06.016 .

Jin, S., and Sader, S.A. 2005. Comparison of time series tasseled cap wetness and the normalized difference moisture index in detecting forest disturbances. Remote Sensing of Environment, Vol. 94 pp. 364-372. doi: 10.1016/j.rse.2004.10.012.

Kauth, R., and Thomas, G. 1976. The Tasseled Cap - a graphic description of the spectral-temporal development of agricultural crops as seen by Landsat. Proceedings of the Symposium on Machine Processing of Remotely Sensed Data, Purdue University, West Lafayette, Indiana, pp. 4B41-4B51.

Kennedy, R.E., Townsend, P.A., Gross, J.E., Cohen, W.B., Bolstad, P., Wang, Y.Q., and Adams, P. 2009. Remote sensing change detection tools for natural resource managers: Understanding concepts and tradeoffs in the design of landscape monitoring projects. Remote Sensing of Environment, Vol. 113, No. 7, pp. 1382-1396. doi: 10.1016/j.rse.2008. 07.018 .

Kuri, S., Nikula, A., Helle, P., and Linden, H. 2000. Landscape fragmentation and forest composition effects on grouse breeding success in boreal forests. Ecology, Vol. 81, No. 7, pp. 1985-1997. doi: 10.1890/ 0012-9658(2000)081[1985:LFAFCE]2.0.CO;2.

Lee, P.G., Hanneman, M., Gysbers, J.D., and Cheng, R. 2009a. The last great intact forests of Canada: Atlas of Alberta. (Part I: Where are the last great intact forest landscapes of Alberta and where is the best of what's left?) Edmonton, Alberta: Global Forest Watch Canada. 92 pp. 
Available online: http://www.globalforestwatch.ca/WBWL/atlasofalberta/ downloads.htm [cited (September 2, 2010)].

Lee, P.G., Hanneman, M., Gysbers, J.D., and Cheng, R. 2009b. The last great intact forests of Canada: Atlas of Alberta. (Part II: What are the threats to Alberta's forest landscapes?) Edmonton Alberta: Global Forest Watch Canada. 145 pp. Available online: http:// www.globalforestwatch.ca/WBWL/atlasofalberta/downloads.htm [cited September 2, 2010].

Lu, D., Mause, P., Brondizios, E., and Moran, E.. 2004. Change detection techniques. International Journal of Remote Sensing, Vol. 5, pp. 2365-2407. doi: $10.1080 / 0143116031000139863$.

Mann, S., and Rothley, K.D. 2006. Sensitivity of Landsat/IKONOS accuracy comparison to errors in photointerpreted reference data and variations in test point sets. International Journal of Remote Sensing, Vol. 27, No. 22, pp. 5027-5036. doi: 10.1080/01431160600784291.

Masek, J.G., Huang, C., Wolfe, R., Cohen, W., Hall, F., Kutler, J., and Nelson, P. 2008. North American forest disturbance mapped from a decadal Landsat record. Remote Sensing of Environment, Vol. 112, No. 6, pp. 2914-2926. doi: 10.1016/j.rse.2008.02.010.

Masters, J.A, (Ed.). 1984. Elmworth, Case Study of a Deep Basin Gas Field. American Association of Petroleum Geologists, Tulsa, Okla., USA.

Mattson, D.J., and Merrill, T. 2002. Extirpations of grizzly bears in the contiguous United States, 1850-2000. Conservation Biology, Vol. 16, No. 4, pp. 1123-1136. doi: 10.1046/j.1523-1739.2002.00414.x.

McLellan, B.N., and Shackleton, D.M. 1988. Grizzly bears and resourceextraction industries: effects of roads on behaviour, habitat use and demography. Journal of Applied Ecology, Vol. 25, No. 2, pp. 451-460. doi: $10.2307 / 2403836$.

Merrill, E., Boyce, M., Allen, J., Frair, J., Vissher, D., Webb, N., Fortin, D., and McInenly, L. 2005. Population monitoring, translocation, and the cumulative effects of industrial activities on elk (Cervus elaphus) in the east central foothills of Alberta, Canada. Department of Biological Sciences, University of Alberta, Edmonton, Alberta.

Nielsen, A., Conradsen, K., and Simpson, J. 1998. Multivariate Alteration and Detection (MAD) and MAF postprocessing in multispectral, bitemporal image data: new approaches to change detection studies. Remote Sensing of Environment, Vol. 64, No. 1, pp. 1-19. doi: 10.1016/ S0034-4257(97)00162-4

Nielsen, S.E. 2004. Habitat ecology, Conservation, and Projected Population Viability of Grizzly Bears (Ursus arctos L.) in West-Central Alberta, Canada. PhD Thesis. Department of Biological Sciences, University of Alberta, Edmonton, Alberta, Canada.

Nielsen, S.E., Boyce, M.S., and Stenhouse, G.B. 2004a. Grizzly bears and forestry I: selection of clearcuts by grizzly bears in west-central Alberta, Canada. Forest Ecology and Management, Vol. 199, No. 1, pp. 51-65. doi: $10.1016 /$ j.foreco.2004.04.014

Nielsen, S.E., Herrero, S., Boyce, M.S., Mace, R.D., Benn, B., Gibeau, M.L., and Jevons, S. 2004b. Modelling the spatial distribution of human-caused grizzly bear mortalities in the Central Rockies ecosystem of Canada. Biological Conservation, Vol. 120, No. 1, pp. 101-113. doi: 10.1016/j.biocon.2004.02.020.

Nielsen, S.E., Cranston, J., and Stenhouse, G.B. 2009. Identification of priority areas for grizzly bear conservation and recovery in Alberta, Canada. Journal of Conservation Planning, Vol. 5, pp. 38-60.
Nielsen, S.E., McDermid, G., Stenhouse, G.B., and Boyce, M.S. 2010. Dynamic wildlife habitat models: seasonal foods and mortality risk predict occupancy-abundance and habitat selection in grizzly bears. Biological Conservation, Vol. 143, pp. 1623-1634.

Oberg, P., Rohner, C., and Schmiegelow, F.K.A. 2003. Responses of mountain caribou to linear features in a west-central Alberta landscape. Proceedings of The Seventh International Symposium on Environmental Concerns in Rights-of-Way Management. Elsevier Science. pp. 455-464.

Patriquin, K.J., and Barclay, R.M.R. 2003. Foraging by bats in cleared, thinned and unharvested boreal forest. Journal of Applied Ecology, Vol. 40, No. 4, pp. 646-657. doi: 10.1046/j.1365-2664.2003.00831.x.

Pease, C.M., and Mattson, D.J. 1999. Demography of the Yellowstone grizzly bears. Ecology, Vol. 80, No. 3, pp. 957-975.

Peterson, U., and Nilson, T. 1993. Successional reflectance trajectories in northern temperate forests. International Journal Remote Sensing, Vol. 14, pp. 609-613. doi: 10.1080/01431169308904361.

Powell, S.L., Cohen, W.B., Yang, ZZ., Pierce, J.D., and Alberti, M. 2008. Quantification of impervious surface in the Snohomish Water Resources Inventory Area of Western Washington from 1972-2006. Remote Sensing of Environment, Vol. 112, No. 4, pp. 1895-1908. doi: 10.1016/ j.rse.2007.09.010.

Powell, S.L., Cohen, W.B., Healey, S.P., Kennedy, R.E., Moisen, G.G., Pierce, K.B., and Ohmann, J.L. 2010. Quantification of live aboveground forest biomass dynamics with Landsat time-series and field inventory data: A comparison of empirical modeling approaches. Remote Sensing of Environment, Vol. 114, No. 5, pp. 1053-1068. doi: 10.1016/j.rse. 2009.12.018.

Price, K.P., and Jakubauskas, M.E. 1998. Spectral retrogression and insect damage in lodgepole pine successional forests. International Journal Remote Sensing, Vol. 19, pp. 1627-1632. doi: 10.1080/014311698215405.

Puyravaud, J.-P. 2003. Standardizing the calculation of the annual rate of deforestation. Forest Ecology and Management, Vol. 177, No. 1-30, pp. 593-596. doi: 10.1016/S0378-1127(02)00335-3.

Riitters, K.H., and Wickham, J.D. 2003. How far to the nearest road? Frontiers in Ecology and the Environment, Vol. 1, No. 3, pp. 125-129. doi: $10.2307 / 3867984$

Ripley, T., Scrimgeour, G., and Boyce, M.S. 2005. Bull trout (Salvelinus confluentus) occurrence and abundance influenced by cumulative industrial developments in a Canadian boreal forest watershed. Canadian Journal of Fisheries and Aquatic Sciences, Vol. 62, No. 11, pp. 24312442. doi: 10.1139/f05-150.

Roland, J. 1993. Large-scale forest fragmentation increases the duration of tent caterpillar outbreak. Oecologia, Vol. 93, No. 1, pp. 25-30.

Rowe, J.S. 1972. Forest regions of Canada. Canadian Forestry Service Department of the Environment, Ottawa, Canada.

Roy, D.P., Ju, J., Lewis, P., Schaaf, C., Gao, F., Hansen, M., and Lindquist, E. 2008. Multi-temporal MODIS-Landsat data fusion for relative radiometric normalization, gap filling, and prediction of Landsat data. Remote Sensing of Environment, Vol. 112, No. 6, pp. 3112-3130. doi: 10.1016/j.rse.2008.03.009.

Schneider, R.R., Stelfox, J.B., Boutin, S., and Wasel, S. 2003. Managing the cumulative impacts of land uses in the Western Canadian Sedimentary Basin: A modeling approach. Ecology and Society, Vol. 7, No. 1 pp. 1-8. 
Schroeder, T.A., Cohen, W.B., Song, C., Canty, M.J., and Yang, Z. 2006. Radiometric correction of multi-temporal Landsat data for characterization of early successional forest patterns in western Oregon. Remote Sensing of Environment, Vol. 103, No. 1, pp. 16-26. doi: 10.1016/j.rse. 2006.03.008.

Schroeder, T.A., Cohen, W.B., and Yang, Z. 2007. Patterns of forest regrowth following clearcutting in western Oregon as determined from a Landsat time series. Forest Ecology and Management, Vol. 243, No. 2-3, pp. 259-273. doi: 10.1016/j.foreco.2007.03.019.

Schwartz, C.C., Swenson, J.E., and Miller, S.D. 2003. Large carnivores, moose, and humans: a changing paradigm of predator management in the 21st century. Alces, Vol. 39, pp. 41-63.

Schwartz, C.C., Haroldson, M.A., White, G.C., Harris, R.B., Cherry, S., Keating, K.A., Moody, D.S., and Servheen, C. 2006. Temporal, spatial, and environmental influences on the demographics of grizzly bears in the Greater Yellowstone ecosystem. Wildlife Monographs, Vol. 161 pp. 1-68. doi: 10.2193/0084-0173(2006)161[1:TSAEIO]2.0.CO;2.

Schwartz, C.C., Haroldson, M.A., and White, G.C. 2010. Hazards affecting grizzly bear survival in the Greater Yellowstone Ecosystem. Journal of Wildlife Management, Vol. 74, No. 4, pp. 654-667. doi: 10.2193/2009206.

Scrimgeour, G.J., Hvenegaard, P., Tchir, J., Kendall, S., and Wildeman, A. 2003. Stream fish management: cumulative effects of watershed disturbances on stream fish communities in the Kakwa and Simonette River Basins, Alberta. Report produced by the Alberta Conservation Association (Peace River) and the Alberta Research Council (Vegreville) for the Northern Watershed Project Stakeholder Committee. Northern Watershed Project Final Report No. 3. 126 pp. Available online: http:// www.ab-conservation.com/go/default/custom/uploads/reportseries2/NWP \%20REPORT\%203.pdf [accessed 2 September 2010].

Scrimgeour, G.J., Hvengaard, P.J., and Tchir, J. 2008. Cumulative industrial activity alters lotic fish assemblages in two boreal forest watersheds of Alberta, Canada. Environmental Management, Vol. 42, No. 6, pp. 957-970. doi: $10.1007 / \mathrm{s} 00267-008-9207-2$.

Skakun, R.S., Wulder, M.A., and Franklin, S.E. 2003. Sensitivity of the Thematic Mapper enhanced wetness difference index to detect mountain pine beetle red-attack damage. Remote Sensing of Environment, Vol. 86, No. 4, pp. 433-443. doi: 10.1016/S0034-4257(03)00112-3.

Statistics Canada. 2008. Road Network File, Reference Guide 92-500-GWE. Statistics Canada, Ottawa, Ontario.

Stenhouse, G.B., and Graham, K, (Eds.). 2005. Foothills Model Forest Grizzly Bear Research Program 1999-2003. Final Report. Foothills Model Forest. 289 pp.

Stewart, B.P., Wulder, M.A., McDermid, G.J., and Nelson, T. 2009. Disturbance capture and attribution through the integration of Landsat and IRS-1C imagery. Canadian Journal of Remote Sensing, Vol. 35, No. 6, pp. 523-533. doi: 10.5589/m10-006.
Tilley, B., and Muehlenbachs, K. 2006. Gas maturity and alteration systematics across Western Canada Sedimentary Basin from four mud gas isotope depth profiles. Organic Geochemistry, Vol. 37, No. 12, pp. 1857-1868. doi: 10.1016/j.orggeochem.2006.08.010.

Toutin, T. 1995. Multisource data integration with an integrated and unified geometric modelling. EARSeL Journal Advances in Remote Sensing, Vol. 4, No. 2, pp. 118-129.

Vaisanen, R.A., Jarvinen, O., and Rauhaula, P. 1986. How are extensive human-caused habitat alterations expressed on the scale of local bird populations in boreal forests? Ornis Scandinavica, Vol. 17, No. 3, pp. 282-292. doi: 10.1016/j.orggeochem.2006.08.010.

Welte, D.H., Schaefer, W., Stoessinger, W., and Radke, M. 1984. Gas generation and migration in the Deep basin of Western Canada. In: Masters, J.A. (Ed.). Elmworth, Case Study of a Deep Basin Gas Field. American Association of Petroleum Geologists Memoir, pp. 35-47.

Wieglus, R.B., and Bunnell, F.L. 2000. Possible negative effects of adult male mortality on female grizzly bear reproduction. Biological Conservation, Vol. 93, No. 2, pp. 145-154. doi: 10.1016/S0006-3207 (99)00152-4.

Woodcock, C.E., Allen, R., Anderson, M., Belward, A., Bindschadler, R., Cohen, W., Gao, F., Goward, S.N., Helder, D., Helmer, E., Nemami, R., Oreopoulos, L., Schott, J., Thenkabail, P.S., Vermote, E.F., Vogelmann, J., Wulder, M.A., and Wynne, R. 2008. Free access to Landsat imagery. Science, Vol. 320, No. 5879, p. 1011. doi: 10.1126/science.320. 5879. 1011a.

Wulder, M.A., Skakun, R., Dymond, C., Kurz, W., and White, J.C. 2005. Characterization of the diminishing detectability of forest insect damage over time. Canadian Journal of Remote Sensing, Vol. 31, No. 6, pp. 421431. doi: $10.5589 / \mathrm{m} 05-026$.

Wulder, M.A., White, J.C., Luther, J.E., Strickland, G., Remmel, T.K., and Mitchell, S.W. 2006. Use of vector polygons for the accuracy assessment of pixel-based land cover maps. Canadian Journal of Remote Sensing, Vol. 32, No. 3, pp. 268-279. doi: 10.5589/m06-023.

Wulder, M.A., White, J.C., Goward, S.N., Masek, J.G., Irons, J.R., Herold, M., Cohen, W.B., Loveland, T.R., and Woodcock, C.E. 2008a. Landsat continuity: Issues and opportunities for land cover monitoring. Remote Sensing of Environment, Vol. 112, No. 3, pp. 955-969. doi: 10.1016/ j.rse.2007.07.004.

Wulder, M.A., White, J.C., Cranny, M, Hall, R.J., Luther, J.E., Beaudoin, A., Goodenough, D.G., and Dechka, J. 2008b. Monitoring Canada's forests. Part 1: Completion of the EOSD land cover project. Canadian Journal of Remote Sensing, Vol. 34, No. 6, pp. 549-548. doi: 10.5589/ m08-066.

Wulder, M.A., White, J.C., Masek, J.G., Dwyer, J., and Roy, D.P. 2011. Continuity of Landsat observations: Short term considerations. Remote Sensing of Environment, Vol. 115, No. 2, pp. 747-751. doi: 10.1016/ j.rse.2010.11.002. 